OPEN ACCESS

Edited by:

Marcelo Rizzatti Luizon,

Federal University of Minas

Gerais, Brazil

Reviewed by:

Ken Batai,

University of Arizona, United States Meenal Gupta,

The University of Utah, United States

*Correspondence:

Elena García-Martín elenag@unex.es

Specialty section:

This article was submitted to

Pharmacogenetics and

Pharmacogenomics,

a section of the journal

Frontiers in Genetics

Received: 12 November 2018 Accepted: 04 June 2019

Published: 25 June 2019

Citation:

Amo G, Martí M, García-Menaya JM

Cordobés C, Cornejo-García JA,

Blanca-López N, Canto G, Doña I,

Blanca M, Torres MJ, Agúndez JAG

and García-Martín E (2019)

Identification of Novel Biomarkers for

Drug Hypersensitivity After

Sequencing of the Promoter Area in 16 Genes of the Vitamin D Pathway

and the High-Affinity IgE Receptor.

Front. Genet. 10:582.

doi: 10.3389/fgene.2019.00582

\section{Identification of Novel Biomarkers for Drug Hypersensitivity After Sequencing of the Promoter Area in 16 Genes of the Vitamin D Pathway and the High-Affinity IgE Receptor}

\author{
Gemma Amo ${ }^{1,2}$, Manuel Martí ${ }^{1,2}$, Jesús M. García-Menaya ${ }^{3,4}$, Concepción Cordobés ${ }^{5,6}$, \\ José A. Cornejo-García ${ }^{7,8}$, Natalia Blanca-López ${ }^{9,10}$, Gabriela Canto ${ }^{9,10}$, \\ Inmaculada Doña ${ }^{11,12}$, Miguel Blanca ${ }^{9,10}$, María José Torres ${ }^{11,12}$, José A. G. Agúndez ${ }^{1,2}$ and \\ Elena García-Martín ${ }^{1,2 *}$ \\ ${ }^{1}$ University Institute of Molecular Pathology Biomarkers, UEx, Cáceres, Spain, ${ }^{2}$ ARADyAL Instituto de Salud Carlos III, \\ Cáceres, Spain, ${ }^{3}$ Allergy Service, Badajoz University Hospital, Badajoz, Spain, ${ }^{4}$ ARADyAL Instituto de Salud Carlos III, \\ Badajoz, Spain, ${ }^{5}$ Allergy Service, Mérida Hospital, Badajoz, Spain, ${ }^{6}$ ARADyAL Instituto de Salud Carlos III, Cáceres, Spain, \\ ${ }^{7}$ Research Laboratory, IBIMA, Regional University Hospital of Málaga, UMA, Málaga, Spain, ${ }^{8}$ ARADyAL Instituto de Salud \\ Carlos III, Cáceres, Spain, ${ }^{9}$ Allergy Service, Infanta Leonor University Hospital, Madrid, Spain, ${ }^{10}$ ARADyAL Instituto de Salud \\ Carlos III, Madrid, Spain, ${ }^{11}$ Allergy Unit, IBIMA, Regional University Hospital of Málaga, UMA, Málaga, Spain, ${ }^{12}$ ARADyAL \\ Instituto de Salud Carlos III, Málaga, Spain
}

The prevalence of allergic diseases and drug hypersensitivity reactions (DHRs) during recent years is increasing. Both, allergic diseases and DHRs seem to be related to an interplay between environmental factors and genetic susceptibility. In recent years, a large effort in the elucidation of the genetic mechanisms involved in these disorders has been made, mostly based on case-control studies, and typically focusing on isolated SNPs. These studies provide a limited amount of information, which now can be greatly expanded by the complete coverage that Next Generation Sequencing techniques offer. In this study, we analyzed the promoters of sixteen genes related to the Vitamin $D$ pathway and the high-affinity IgE receptor, including FCER1A, MS4A2, FCER1G, VDR, GC, CYP2R1, CYP27A1, CYP27B1, CYP24A1, $R X R A, R X R B, R X R G, I L 4, I L 4 R, I L 13$, and IL13RA1. The study group was composed of patients with allergic rhinitis plus asthma $(A R+A)$, patients with hypersensitivity to beta-lactams (BLS), to NSAIDs including selective hypersensitivity (SH) and crossreactivity (CR), and healthy controls without antecedents of atopy or adverse drug reactions. We identified 148 gene variations, 43 of which were novel. Multinomial analyses revealed that three SNPs corresponding to the genes FCER1G (rs36233990 and rs2070901), and GC (rs3733359), displayed significant associations and, therefore, were selected for a combined dataset study in a cohort of 2,476 individuals. The strongest association was found with the promoter FCER1G rs36233990 SNP that alters a transcription factor binding site. This SNP was over-represented among $\mathrm{AR}+\mathrm{A}$ patients and among patients with lgE-mediated diseases, as compared with control individuals or with the rest of patients in this study. Classification 
models based on the above-mentioned SNPs were able to predict correct clinical group allocations in patients with DHRs, and patients with IgE-mediated DHRs. Our findings reveal gene promoter SNPs that are significant predictors of drug hypersensitivity, thus reinforcing the hypothesis of a genetic predisposition for these diseases.

Keywords: Next-Generation Sequencing (NGS), vitamin D, high-affinity IgE receptor (FC\&RI), NSAIDs (non-steroidal anti-inflammatory drugs), beta-lactam antibiotic, drugs hypersensitivity reactions, allergic rhinitis, asthma

\section{INTRODUCTION}

The prevalence of atopy, allergic diseases, and drug hypersensitivity reactions (DHRs) is increasing worldwide. In Europe, studies have estimated a prevalence of 20$25 \%$ allergic diseases in adults, with many young people being unaware of their disease (Linneberg, 2011; Kruse and Vanijcharoenkarn, 2018), which means an important economic impact for healthcare (European Commission, 2008; Bouvy et al., 2015) reaching an amount from $€ 55$ to $€ 151$ billion per year in European Union, including indirect costs related to the absence or reduced productivity at work (Zuberbier et al., 2014; Kruse and Vanijcharoenkarn, 2018). Due to their complexity, it is difficult to understand the specific mechanisms and molecules involved in the development of these diseases or to establish a way to prevent or reduce them. Allergic rhinitis (AR) reduces the quality of life by affecting sleep, school, work productivity, and social life. AR is an immunoglobulin E (IgE) mediated inflammatory disease, which is associated with other inflammatory diseases such as asthma. It has been estimated that around $20 \%$ of people in the USA and Europe suffer from allergic rhinitis (Durham et al., 2012; Ozdoganoglu and Songu, 2012; Rondon et al., 2017). Taking this into consideration, AR has been classified as a major chronic respiratory disease (Brozek et al., 2017). Drug hypersensitivity reactions (DHR) account for, $\sim 3$ to $6 \%$ of all hospital admissions. These reactions occur in 10 to $15 \%$ of hospitalized patients (Gomes and Demoly, 2005; Szczeklik and Nizankowska-Mogilnicka, 2009; Doña et al., 2014). Beta-lactam antibiotics (BLs) are the most common cause of DHRs mediated by specific immunological mechanisms (Antúnez et al., 2006; Doña et al., 2012, 2014) and, although the mechanisms of how the immune system recognizes these drugs are not fully determined, BLs are considered the classical model of this type of reactions (Blanca et al., 2009). Together with BLs, non-steroidal anti-inflammatory drugs (NSAIDs) are account for the vast majority of DHRs (Gomes et al., 2004; Messaad et al., 2004; Chen et al., 2012; Doña et al., 2012), but, in this case, these DHRs are not exclusively mediated by specific immunological mechanisms (selective hypersensitivity), involving a response to a single drug and good tolerance to other chemically unrelated NSAIDs (Canto et al., 2009; Cornejo-Garcia et al., 2009); but also by nonspecific immunological mechanisms (cross-reactions), which can be caused by more than one chemically unrelated NSAIDs (Agúndez et al., 2012; Kowalski et al., 2013).

Recent investigation proposes the vitamin D pathway among putative factors linked to allergic diseases, because of its important role in immune system (Veldman et al., 2000;
Cantorna et al., 2015) and its direct relation with allergic diseases (Black and Scragg, 2005; Camargo et al., 2007; Benson et al., 2012; Suaini et al., 2015). There are many molecules involved in the vitamin D pathway: hydroxylases from CYP450 family, such as CYP27A1, CYP27B1, CYP2R1, and CYP24A1; the vitamin D binding protein (GC) that acts like a transporter, the vitamin $\mathrm{D}$ receptor (VDR), the retinoid receptor X (RXR) and interleukins which participate in downstream pathway (IL4 and IL13). In addition, there are other target molecules and signaling pathways, which could be involved in allergic mechanisms, such as the high-affinity IgE Receptor (FCERI), which plays a key role in allergic reactions. This receptor is stimulated by IgE, triggering mast cells and basophils activation, and the consequent release of inflammatory mediators. In human mast cells and basophils, FCERI consist of a heterotetramer composed by three subunits: $\mathrm{FC} \varepsilon \mathrm{RI} \alpha$, the ligand-binding subunit which is encoded by FCER $1 A$ gene; FCERI $\beta$, a signal-augmenting subunit encoded by MS4A2; and $\mathrm{FC} \varepsilon \mathrm{RI} \gamma$, a signal-transducing subunit that is presented like a dimer and it is encoded by FCER1G (Kinet, 1999; Potaczek and Kabesch, 2012). Elevated levels of IgE have been detected in atopic conditions like allergic rhinitis, asthma, atopic dermatitis, anaphylaxia (Platts-Mills, 2001; Wallace et al., 2008) thus making FCERI a plausible target molecule in the study of the mechanisms involved in the development and in the clinical presentation of allergy.

It could be hypothesized that variations related to expression and/or function in genes of the vitamin $\mathrm{D}$ signaling pathways or FCERI might modify the risk of developing rhinitis or DHRs, and/or the presentation of clinical manifestations of these reactions. As a matter of fact, several studies demonstrated an association between different allergic diseases, including DHRs, and polymorphisms in these genes (Poon et al., 2004; Raby et al., 2004; Donfack et al., 2005; Bossé et al., 2009; Saadi et al., 2009; Pillai et al., 2011; Micheal et al., 2013; Berenguer et al., 2014; Amo et al., 2016a; Narozna et al., 2016). Several studies addressed the putative impact of exonic and intronic SNPs within the abovementioned genes and the risk of allergic diseases and/or DHR (Wjst, 2005; Wjst et al., 2006; Battle et al., 2007; Arshad et al., 2008; Sadeghnejad et al., 2008; Weidinger et al., 2008; Black et al., 2009; Bossé et al., 2009; Ferreira et al., 2009; Knutsen et al., 2010; Li et al., 2010, 2012, 2014, 2016; Michel et al., 2010; Moffatt et al., 2010; Cooper et al., 2011; Joubert et al., 2011; Liu et al., 2011; Lu et al., 2011; Park et al., 2011; Paternoster et al., 2011; Pillai et al., 2011; Burkhardt et al., 2012; Choi et al., 2012; Granada et al., 2012; Lasky-Su et al., 2012; Ramasamy et al., 2012; Robinson et al., 2012; Zhou et al., 2012; Anderson et al., 2013; Hur et al., 2013; Ismail et al., 2013; Movahedi et al., 2013; Potaczek et al., 
2013; Sharma et al., 2014; Yang et al., 2014; Kumar et al., 2015; Papadopoulou et al., 2015; Pino-Yanes et al., 2015; Tian et al., 2015; Amo et al., 2016a,b; Han et al., 2016; Karaca et al., 2016; Narozna et al., 2016; Overton et al., 2016; Ådjers et al., 2017; Ashley et al., 2017; Park and Tantisira, 2017; Sun et al., 2017; Xu et al., 2017; Zhang et al., 2017; Zhao et al., 2017). However, there is little information about SNPs located in the promoters of these genes, which might have functional consequences.

In an attempt to identifying genetic susceptibility factors associated with allergy and/or DHRs, that may provide novel information to gain a better understanding of these pathologies, we carried out an exhaustive analysis of genetic variations situated in the promoter region of the mentioned genes by using Next Generation Sequencing (NGS) in patients with allergic rhinitis plus asthma $(\mathrm{AR}+\mathrm{A})$, BLs hypersensitivity, selective NSAIDs hypersensitivity (SH) and cross-reactions to NSAIDs (CR), as well as in healthy control individuals. The genes included in the study were FCER1A, MS4A2, FCER1G, VDR, GC, CYP2R1, CYP27A1, CYP27B1, CYP24A1, RXRA, RXRB, RXRG, IL4, IL4R, $I L 13$, and IL13RA1. In addition, we also analyzed the interaction of genetic and non-genetic factors, such as age, gender, and antecedents of atopy, in the risk of developing these diseases.

\section{PATIENTS AND METHODS}

\section{Study Population}

A total cohort of 2,476 individuals participated in this study. All were Caucasian Spanish individuals. These included 406 healthy controls without antecedents of atopy or adverse drug reactions, 528 patients with $\mathrm{AR}+\mathrm{A}, 561$ individuals with $\mathrm{BLs}$ hypersensitivity, 668 patients with NSAIDs cross-reactivity (CR), and 313 selective hypersensitivity patients $(\mathrm{SH})$ which were single-NSAIDs responders. Written consent for participation was obtained for all participants. Patients were recruited at Hospitals participating in the study. All the patients who were invited to participate in the study agreed to do so. Control individuals were selected among students and staff in the University and Hospitals participating in the study. Characteristics of the study groups are summarized in Table 1. The diagnosis was carried out as described elsewhere (García-Martín et al., 2007; Doña et al., 2011; Amo et al., 2016a; Lacombe-Barrios, 2018). The protocol for this study was in accordance with the Declaration of Helsinki and its subsequent revisions and was approved by the respective Ethics Committees of the participating Hospitals.

To get a further analysis of the sample, we put together some of the groups of patients which share a specific characteristic. Thus, we defined three new groups of study: "DHR group," were we included all the patients with DHR: namely, patients with hypersensitivity to BLs and NSAIDs (both, CR and SH); "DHRIgE Group," which comprises selective hypersensitivity to BLs and SH; and "IgE Mediated Group," where we included all the IgE-mediated reactions (AR+A, BLs and $\mathrm{SH})$.

\section{Identification of Novel Variants Using NGS}

A subset of participants were selected for this phase. A total cohort of 175 individuals participated in this NGS analysis. These included 22 healthy controls without antecedents of atopy or adverse drug reactions, 22 patients with $\mathrm{AR}+\mathrm{A}, 43$ individuals with BLs hypersensitivity, 41 patients with NSAIDs cross-reactivity (CR), and 46 selective hypersensitivity patients (SH) which were single-NSAIDs responders. Characteristics of the participants are summarized in Table S1. Genomic DNA was obtained from leukocytes and purified according to standard procedures. DNA samples were analyzed by NGS after specific enrichment based on the Haloplex design. Details of the areas sequenced are shown in Table S2. DNA was digested with restriction enzymes specific for this design (Haloplex, Agilent, Santa Clara, CA, USA), followed by hybridization with specific probes, DNA circularization and selection of the target areas, according to the protocol supplied. Sequencing was carried out in a MiSeq sequencer (Illumina, San Diego, CA, USA) using the pair end format. The coverage was always higher than that recommended by the manufacturer $(23.7 \mathrm{Mb}$ per sample). All variants identified had at least a $50 \mathrm{X}$ coverage and more than $95 \%$ of these had more than $100 \mathrm{x}$ coverage. The sequencing results were analyzed by using the application SureCall 4.0 (Agilent, Santa Clara, CA, USA), adapted to the analysis of enriched Haloplex sequences, and MiseqReporter V04 (Illumina, San Diego, CA). Sequence revision against human genome was carried out by using the Integrative Genomes Viewer (Broad Institute, Cambridge, MA, USA).

\section{Combined Dataset Analyses}

All patients and controls participated in this phase. Analyses were carried out by using TaqMan genotyping focused on the SNVs raised after multiple comparison analyses of the NGS phase (see the results section for further details). The SNPs were analyzed in triplicate, by using SNP TaqMan assays (Life Technologies S.A., Alcobendas, Madrid, Spain), and following the conditions specified by the manufacturer. Assay details are as follows: FCER1G-rs36233990, Custom TaqMan ${ }^{\circledR}$ Assay; FCER1G-rs2070901, (C_15867981_20); and GC-rs3733359, (C_25652813_40).

\section{Statistical Analysis}

The R package SNPasoc (Gonzalez et al., 2014) was used to calculate allele and genotypic frequencies, to determine the Hardy-Weinberg equilibrium using exact test (Wigginton, 2005) and to analyse differences between groups (González et al., 2007). The comparison between groups was performed with the Fisher's Exact Test (FET) and Likelihood Ratio Test (LRT) with an initial crude analysis followed by an adjusted analysis including gender as the categorical covariate when it was possible. False Discovery Rate (FDR) correction was used for the multiple comparison adjustments (Benjamini et al., 2001). The results were considered statistically significant when $P$-values were under 0.05 . The association between SNPs and traits was estimated by odds ratio (OR) with a $95 \%$ confidence interval (CI) or by Relative Risk (RR) when the variation was not found in the control group. The Relative Risk was calculated by using EpiBasic, a tool for statistical analysis of tabular information, performing a stratified analysis, using the inverse variance $\left(1 / \mathrm{SE}^{2}\right)$ as weigh. This tool was developed as a companion to a Danish textbook on epidemiology (Juul, 2012), and the 
TABLE 1 | Characteristics of the participants.

\begin{tabular}{lccccc}
\hline & $\begin{array}{c}\text { Healthy controls } \\
(\boldsymbol{n}=\mathbf{4 0 6 )}\end{array}$ & $\begin{array}{c}\text { Patients with AR+A } \\
(\boldsymbol{n}=\mathbf{5 2 8})\end{array}$ & $\begin{array}{c}\text { Patients with BLs } \\
\text { hypersensitivity } \\
(\boldsymbol{n}=\mathbf{5 6 1})\end{array}$ & $\begin{array}{c}\text { Patients with NSAIDs } \\
\text { cross-reactions (CR) } \\
(\boldsymbol{n}=\mathbf{6 6 8})\end{array}$ & $\begin{array}{c}\text { Patients with NSAIDs } \\
\text { selective hypersensitivity (SH) } \\
(\boldsymbol{n}=\mathbf{3 1 3})\end{array}$ \\
\hline Women. $n(\%)$ & $253(62.3 \%)$ & $292(55.3 \%)$ & $318(56.7 \%)$ & $390(58.4 \%)$ & $204(65.2 \%)$ \\
Age + sd (range) & $22.1 \pm 4.7(20-58)$ & $32.4 \pm 14.2(14-79)$ & $46.7 \pm 14.5(4-91)$ & $41.8 \pm 15.3(5-92)$ & $45.5 \pm 16.0(5-82)$ \\
Antecedents of atopy & 0 & $100 \%$ & $23.3 \%$ & $20.8 \%$ & $23.3 \%$ \\
\hline
\end{tabular}

spreedsheat could be download from the following link (Juul and Frydenberg, 2016): http://ph.medarbejdere.au.dk/undervisningog-uddannelse/software/.

Association between each SNP and each clinical phenotype was assessed by using binary logistic regression. Then, predictive Models based on Multinomial Logistic Regression (MLR) (Agresti, 2003) were performed for SNPs showing association in the binary regression analyses by using SPSS (IBM SPSS Statistics for Windows, Version 22.0). The $p$-values associated with every SNP were calculated using the Chi-Square test. Each model has associated several pseudo- $\mathrm{R}^{2}$ coefficients as indicators of the strength of the association between the response and the predictor variables. Cox and Snell is based on the loglikelihood for the model compared to the log likelihood for a baseline model and it has a theoretical maximum value of $<1$, even for a "perfect" model (Cox and Snell, 1989) and Nagelkerke is an adjusted version of the Cox \& Snell $R$-square that adjusts the scale of the statistic to cover the full range from 0 to 1 (Nagelkerke, 1991). McFadden is another version, based on the log-likelihood kernels for the intercept-only model and the full estimated model. This is the pseudo- $\mathrm{R}^{2}$ coefficient most frequently used and the correlation between variables is good when the values are comprised between 0.2 and 0.4 , and better up to 0.4 (McFadden, 1974, 1977). The first model includes all the groups separately, that is, $\mathrm{AR}+\mathrm{A}, \mathrm{BLs}, \mathrm{CR}$ and $\mathrm{SH}$. Model 2 considered two groups of patients: $A R+A$ and a group combining all DRH patients. Model 3 considered three groups of patients: AR + A, patients with Ige-Mediated DHR, and patients with DHR not related to IgE (that is, CR patients). For all models the control group was always the reference group. Coefficients were calculated by dropping samples with missing data in explanatory variables, which have been selected using stepwise regression method. The statistical power was calculated from variant allele frequencies with a genetic model analysing the frequency for carriers of the disease gene with a $R R$ value $=2$ ( $p=0.05)$ for the genetic associations identified in the combined dataset model as described elsewhere (Pértegas Díaz and Pita Fernández, 2003). These values are shown in Table S3. The functional impact of the gene variants was analyzed by using TRANSFAC (Matys et al., 2003, 2006).

\section{RESULTS}

\section{Identification of Novel Variants Using NGS}

In this phase we identified 148 variations situated in the promoter region of genes related with vitamin $\mathrm{D}$ and FCERI genes.
The information about the variations, their frequency in the whole sample and the Hardy-Weinberg equilibrium values is summarized in Table 2. It is to be noted that 84 out of the 148 (56.7\%) of the SNPs identified in this study were found in cases only and not in control individuals.

Among the 148 gene variations identified, 43 were novel. Within the 105 already described SNPs, 25 have not been described or studied earlier in European individuals, although they show marginal MAF in our study (only three SNPs show MAF above 0.010). Regarding known SNPs, the frequencies are concordant with the results previously described in the 1,000 Genomes public database (http://grch37.ensembl.org/ index.html) for individuals with European descent for all the variations except for the rs4020369 SNP in the GC gene, where the described frequency for Europeans is equal to 0 , but in our population it shows a MAF close to 0.040 , that is in agreement with the global frequency described in 1,000 Genomes for overall individuals.

One hundred and three out of the 148 variants identified were at Hardy-Weinberg equilibrium (HWE) in the overall study population (see Table S4), which is to be expected given the high number of SNPs analyzed and the limited sample size in the NGS analyses. Within the 45 variants that were not in HWE, only 7 showed a MAF $>0.050$ in agreement with frequencies described in literature. We carried out binary logistic regression analyses excluding those variants with MAF $<0.02$ (see Table 2). Results of the regression analyses are shown in Table S5. Among the 44 variants we selected those with adjusted $P \leq 0.10$ for multinomial analyses. Therefore, 25 variants were included in the multinomial analysis as well as gender, antecedents of atopy and clinical group (Allergic rhinitis + Asthma; BLs, CR and $\mathrm{SH})$. It is to be noted that some SNPs with a high significance after logistic binary regression analyses (See Table S5), such as rs1467664 (RXRG), rs3733359 (GC), rs2070874 (IL4), rs4303288, and rs4307775 (VDR) and rs2259735 (CYP24A1), were not significant after multinomial analysis. The statistically significant variables raised after this analysis were three SNPs (FCER1G rs36233990, FCER1G rs2070901, and GC rs3733359), as well as antecedents of atopy.

\section{Combined Dataset Analyses}

The three SNPs mentioned above were analyzed in the whole study group. The FCER1G rs36233990 SNP was monomorphic in the control group, whereas heterozygous subjects were identified in all subgroups of patients and homozygous individuals were identified in the AR+A and CR groups. Statistically significant 
TABLE 2 | SNPS with MAF $\geq 0.02$ observed in the NGS study.

\begin{tabular}{|c|c|c|c|c|c|c|c|c|c|}
\hline Gene & dbSNP & $\begin{array}{l}\text { Chromosomal } \\
\text { Location }\end{array}$ & Alleles & MAF & HWE & $\begin{array}{c}\text { MAF 1,000 } \\
\text { Genomes } \\
\text { ALL } \\
\text { individuals }\end{array}$ & $\begin{array}{c}\text { MAF 1,000 } \\
\text { Genomes } \\
\text { European } \\
\text { individuals }\end{array}$ & $\begin{array}{c}\text { MAF } \\
\text { genomAD } \\
\text { ALL } \\
\text { individuals }\end{array}$ & $\begin{array}{c}\text { MAF } \\
\text { genomAD } \\
\text { European } \\
\text { individuals }\end{array}$ \\
\hline FCER1A & rs2427837 & 1:159258545 & $\mathrm{G} / \mathrm{A}$ & $0.213 \mathrm{~A}$ & 0.501 & $0.151 \mathrm{~A}$ & $0.304 \mathrm{~A}$ & $0.217 \mathrm{~A}$ & $0.289 \mathrm{~A}$ \\
\hline FCER1A & rs61828219 & $1: 159258641$ & $\mathrm{C} / \mathrm{A}$ & $0.141 \mathrm{~A}$ & 0.752 & $0.085 \mathrm{~A}$ & $0.160 \mathrm{~A}$ & $0.129 \mathrm{~A}$ & $0.175 \mathrm{~A}$ \\
\hline FCER1A & rs12135235 & 1:159259029 & $T / G$ & $0.043 G$ & 1.000 & $0.033 \mathrm{G}$ & $0.033 \mathrm{G}$ & $0.034 \mathrm{G}$ & $0.037 \mathrm{G}$ \\
\hline FCER1G & None & 1:161184792 & GTCTCAAAAA/G & $0.023 \mathrm{G}$ & 1.000 & - & - & - & - \\
\hline FCER1G & None & $1: 161184793$ & TCTCAAAAA/T & $0.026 \mathrm{~T}$ & 1.000 & - & - & - & - \\
\hline FCER1G & None & $1: 161184794$ & CTCAAAAAA/C & $0.052 \mathrm{C}$ & 1.000 & - & - & - & - \\
\hline FCER1G & None & 1:161184795 & TCAAAAATT & $0.121 \mathrm{~T}$ & 0.474 & - & - & - & - \\
\hline FCER1G & None & 1:161184796 & $\mathrm{C} / \mathrm{A}$ & $0.020 \mathrm{~A}$ & 0.000 & - & - & - & - \\
\hline RXRG & rs1467664 & $1: 165414933$ & $\mathrm{~T} / \mathrm{C}$ & $0.178 \mathrm{C}$ & 0.073 & $0.203 C$ & $0.142 \mathrm{C}$ & $0.181 \mathrm{C}$ & $0.138 \mathrm{C}$ \\
\hline $\mathrm{GC}$ & rs3733359 & 4:72649774 & $\mathrm{G} / \mathrm{A}$ & $0.069 \mathrm{~A}$ & 0.894 & $0.206 \mathrm{~A}$ & $0.055 \mathrm{~A}$ & $0.122 \mathrm{~A}$ & $0.060 \mathrm{~A}$ \\
\hline $\mathrm{GC}$ & rs76781122 & 4:72669661 & $\mathrm{C} / \mathrm{A}$ & $0.034 \mathrm{~A}$ & 1.000 & $0.013 \mathrm{~A}$ & $0.034 \mathrm{~A}$ & $0.019 \mathrm{~A}$ & $0.028 \mathrm{~A}$ \\
\hline GC & rs6843222 & 4:72669944 & $\mathrm{C} / \mathrm{T}$ & $0.029 \mathrm{~T}$ & 1.000 & $0.004 \mathrm{~T}$ & $0.016 \mathrm{~T}$ & $0.007 \mathrm{~T}$ & $0.011 \mathrm{~T}$ \\
\hline $\mathrm{GC}$ & rs35096193 & 4:72670093 & $\mathrm{C} / \mathrm{A}$ & $0.236 \mathrm{~A}$ & 0.059 & $0.165 \mathrm{~A}$ & $0.284 \mathrm{~A}$ & $0.203 \mathrm{~A}$ & $0.272 \mathrm{~A}$ \\
\hline $\mathrm{GC}$ & rs1565572 & 4:72670191 & $\mathrm{A} / \mathrm{C}$ & $0.210 \mathrm{C}$ & 0.499 & $0.432 \mathrm{C}$ & $0.196 \mathrm{C}$ & $0.363 \mathrm{C}$ & $0.192 \mathrm{C}$ \\
\hline GC & rs4020369 & 4:72670448 & $\mathrm{G} / \mathrm{A}$ & $0.037 \mathrm{~A}$ & 1.000 & $0.033 \mathrm{~A}$ & 0 & $0.037 \mathrm{~A}$ & $0.008 \mathrm{~A}$ \\
\hline IL13 & None & 5:131992098 & $\mathrm{G} / \mathrm{C}$ & $0.023 \mathrm{C}$ & 0.000 & - & - & - & - \\
\hline IL13 & rs1800925 & 5:131992809 & $\mathrm{C} / \mathrm{T}$ & $0.223 \mathrm{~T}$ & 0.001 & $0.255 \mathrm{~T}$ & $0.178 \mathrm{~T}$ & $0.270 \mathrm{~T}$ & $0.226 \mathrm{~T}$ \\
\hline IL13 & rs2066960 & $5: 131994435$ & $\mathrm{C} / \mathrm{A}$ & $0.082 \mathrm{~A}$ & 1.000 & $0.199 \mathrm{~A}$ & $0.115 \mathrm{~A}$ & $0.176 \mathrm{~A}$ & $0.125 \mathrm{~A}$ \\
\hline MS4A2 & rs1441585 & $11: 59855711$ & $\mathrm{~T} / \mathrm{C}$ & $0.032 \mathrm{C}$ & 1.000 & $0.112 \mathrm{C}$ & $0.038 \mathrm{C}$ & - & - \\
\hline MS4A2 & rs1441586 & $11: 59856028$ & $\mathrm{~T} / \mathrm{C}$ & $0.414 \mathrm{C}$ & 0.755 & $0.460 \mathrm{C}$ & $0.456 C$ & $0.425 \mathrm{C}$ & $0.418 \mathrm{C}$ \\
\hline VDR & rs117397914 & $12: 48276613$ & $A / G$ & $0.031 \mathrm{G}$ & 0.150 & $0.009 G$ & $0.018 \mathrm{G}$ & $0.011 \mathrm{G}$ & $0.016 \mathrm{G}$ \\
\hline VDR & rs11168293 & $12: 48293716$ & $\mathrm{G} / \mathrm{T}$ & $0.284 \mathrm{~T}$ & 0.712 & $0.166 \mathrm{~T}$ & $0.321 \mathrm{~T}$ & $0.282 \mathrm{~T}$ & $0.355 \mathrm{~T}$ \\
\hline VDR & rs4303288 & $12: 48336619$ & $\mathrm{~A} / \mathrm{C}$ & $0.467 \mathrm{C}$ & 0.035 & $0.404 \mathrm{~A}$ & $0.397 \mathrm{~A}$ & $0.402 \mathrm{~A}$ & $0.389 \mathrm{~A}$ \\
\hline VDR & rs4307775 & $12: 48336623$ & $\mathrm{C} / \mathrm{G}$ & $0.139 G$ & 0.000 & $0.171 \mathrm{G}$ & $0.209 G$ & $0.185 G$ & $0.249 \mathrm{G}$ \\
\hline IL4R & rs12927172 & $16: 27325021$ & $G / A$ & $0.424 \mathrm{~A}$ & 0.013 & $0.405 \mathrm{~A}$ & $0.372 \mathrm{~A}$ & $0.353 \mathrm{~A}$ & $0.367 \mathrm{~A}$ \\
\hline IL4R & rs12927543 & $16: 27325023$ & $A / G$ & $0.109 \mathrm{G}$ & 0.125 & $0.082 \mathrm{G}$ & $0.088 \mathrm{G}$ & $0.066 \mathrm{G}$ & $0.080 \mathrm{G}$ \\
\hline CYP24A1 & rs35873579 & 20:52788190 & $\mathrm{G} / \mathrm{A}$ & $0.023 \mathrm{~A}$ & 1.000 & $0.001 \mathrm{~A}$ & $0.004 \mathrm{~A}$ & $0.002 \mathrm{~A}$ & $0.003 \mathrm{~A}$ \\
\hline CYP24A1 & rs36106327 & 20:52788294 & $\mathrm{C} / \mathrm{A}$ & $0.026 \mathrm{~A}$ & 0.100 & $0.007 \mathrm{~A}$ & $0.020 \mathrm{~A}$ & $0.010 \mathrm{~A}$ & $0.016 \mathrm{~A}$ \\
\hline CYP24A1 & rs2259735 & $20: 52788314$ & $\mathrm{~T} / \mathrm{C}$ & $0.455 \mathrm{C}$ & 0.029 & $0.566 \mathrm{C}$ & $0.420 \mathrm{C}$ & $0.515 \mathrm{C}$ & $0.408 \mathrm{C}$ \\
\hline CYP24A1 & rs2762943 & 20:52790786 & $\mathrm{G} / \mathrm{T}$ & $0.095 \mathrm{~T}$ & 0.652 & $0.034 \mathrm{~T}$ & $0.085 \mathrm{~T}$ & $0.037 \mathrm{~T}$ & $0.081 \mathrm{~T}$ \\
\hline CYP24A1 & rs2585427 & 20:52790976 & $\mathrm{G} / \mathrm{C}$ & $0.376 \mathrm{C}$ & 0.873 & $0.444 \mathrm{C}$ & $0.390 \mathrm{C}$ & $0.447 \mathrm{C}$ & $0.373 \mathrm{C}$ \\
\hline IL13RA1 & rs6603441 & $X: 117861321$ & $T / G$ & $0.356 \mathrm{G}$ & 0.000 & $0.452 \mathrm{G}$ & $0.315 G$ & $0.407 \mathrm{G}$ & $0.322 \mathrm{G}$ \\
\hline
\end{tabular}

-, not described; MAF, Minor Allele Frequency.

differences were identified for this SNP in all subgroups of patients (Table 3), although after FDR correction differences remained significant for the $\mathrm{AR}+\mathrm{A}$ and $\mathrm{BLs}$ groups. The FCER1G rs2070901 SNP had a marginal trend toward higher frequency of the variant allele among CR patients, which was not statistically significant after FDR analysis. These two FCER1G SNPs are not 
TABLE 3 | Combined dataset analyses.

\begin{tabular}{|c|c|c|c|c|c|c|c|c|c|c|c|c|c|c|}
\hline \multirow[b]{2}{*}{ SNP ID } & \multirow[b]{2}{*}{ Genotype } & \multirow[b]{2}{*}{$\begin{array}{l}\text { Control } \\
\text { frequency }\end{array}$} & \multicolumn{3}{|c|}{$\begin{array}{l}\text { Rhinits+Asthma (AR+A) vs. } \\
\text { controls comparison values } \\
\qquad(N=528 \text { vs. } 406)\end{array}$} & \multicolumn{3}{|c|}{$\begin{array}{l}\text { Bls vs. Controls comparison } \\
\text { values }(N=561 \text { vs. } 406)\end{array}$} & \multicolumn{3}{|c|}{$\begin{array}{l}\text { CR vs. Controls comparison } \\
\text { values }(N=668 \text { vs. } 406)\end{array}$} & \multicolumn{3}{|c|}{$\begin{array}{l}\text { SH vs. Controls comparison } \\
\text { values }(N=313 \text { vs. } 406)\end{array}$} \\
\hline & & & $\begin{array}{c}A R+A \\
\text { frequency }\end{array}$ & $\begin{array}{l}\text { OR }(95 \% \mathrm{Cl}) \\
\text { with } \\
\text { covariates } \\
\text { (1) (2) }\end{array}$ & $\begin{array}{l}P_{\text {cov }} \\
\text { (FDR) (2) }\end{array}$ & $\begin{array}{l}\text { BLs } \\
\text { frequency }\end{array}$ & $\begin{array}{l}\text { OR (95\% Cl) } \\
\text { with } \\
\text { covariates } \\
\text { (1) (2) }\end{array}$ & $\begin{array}{c}P_{\text {cov }} \\
\text { (FDR) (2) }\end{array}$ & $\begin{array}{c}\text { CR } \\
\text { Frequency }\end{array}$ & $\begin{array}{l}\text { OR }(95 \% \mathrm{Cl}) \\
\text { with } \\
\text { covariates } \\
\text { (1) (2) }\end{array}$ & $\begin{array}{c}P_{\text {cov }} \\
\text { (FDR) (2) }\end{array}$ & $\begin{array}{c}\text { SH } \\
\text { Frequency }\end{array}$ & $\begin{array}{l}\text { OR (95\% CI) } \\
\text { with } \\
\text { covariates } \\
\text { (1) (2) }\end{array}$ & $\begin{array}{l}P_{\text {cov }} \\
\text { (FDR) (2) }\end{array}$ \\
\hline \multirow[t]{3}{*}{$\begin{array}{l}\text { FCER1G- } \\
\text { rs36233990 }\end{array}$} & $\mathrm{C} / \mathrm{C}$ & 1 & 0.953 & 1.00 & $\begin{array}{l}0.000 \\
(0.000)\end{array}$ & 0.991 & 1.00 & $\begin{array}{c}0.025 \\
(0.041)\end{array}$ & 0.990 & 1.00 & $\begin{array}{l}0.043 \\
(0.071)\end{array}$ & 0.993 & 1.00 & $\begin{array}{l}0.077 \\
(0.231)\end{array}$ \\
\hline & $\mathrm{C} / \mathrm{T}$ & 0 & 0.045 & $\begin{array}{c}1.76 \\
(1.66-1.86)\end{array}$ & & 0.009 & $\begin{array}{c}1.67 \\
(1.53-1.76)\end{array}$ & & 0.008 & * & & 0.007 & * & \\
\hline & $\mathrm{T} / \mathrm{T}$ & 0 & 0.002 & * & & - & - & & 0.002 & * & & 0 & - & \\
\hline \multirow[t]{3}{*}{$\begin{array}{l}\text { FCER1G- } \\
\text { rs2070901 }\end{array}$} & $\mathrm{G} / \mathrm{G}$ & 0.482 & 0.531 & 1.00 & $\begin{array}{l}0.065 \\
(0.097)\end{array}$ & 0.545 & 1.00 & $\begin{array}{c}0.073 \\
(0.073)\end{array}$ & 0.524 & 1.00 & $\begin{array}{l}0.047 \\
(0.071)\end{array}$ & 0.521 & 1.00 & $\begin{array}{l}0.328 \\
(0.492)\end{array}$ \\
\hline & $\mathrm{G} / \mathrm{T}$ & 0.453 & 0.381 & $\begin{array}{c}0.75 \\
(0.56-0.99)\end{array}$ & & 0.380 & $\begin{array}{c}0.73 \\
(0.55-0.96)\end{array}$ & & 0.382 & $\begin{array}{c}0.77 \\
(0.59-1.01)\end{array}$ & & 0.399 & $\begin{array}{c}0.81 \\
(0.59-1.11)\end{array}$ & \\
\hline & $\mathrm{T} / \mathrm{T}$ & 0.065 & 0.088 & $\begin{array}{c}1.18 \\
(0.69-2.00)\end{array}$ & & 0.075 & $\begin{array}{c}1.00 \\
(0.58-1.72)\end{array}$ & & 0.094 & $\begin{array}{c}1.32 \\
(0.80-2.20)\end{array}$ & & 0.080 & $\begin{array}{c}1.13 \\
(0.62-2.06)\end{array}$ & \\
\hline \multirow[t]{3}{*}{ GC-rs3733359 } & $G / G$ & 0.874 & 0.892 & 1.00 & $\begin{array}{c}0.646 \\
(0.646)\end{array}$ & 0.910 & 1.00 & $\begin{array}{l}0.027 \\
(0.041)\end{array}$ & 0.901 & 1.00 & $\begin{array}{c}0.212 \\
(0.212)\end{array}$ & 0.886 & 1.00 & $\begin{array}{c}0.632 \\
(0.632)\end{array}$ \\
\hline & $\mathrm{G} / \mathrm{A}$ & 0.118 & 0.104 & $\begin{array}{c}0.88 \\
(0.57-1.36)\end{array}$ & & 0.090 & $\begin{array}{c}0.73 \\
(0.47-1.13)\end{array}$ & & 0.098 & $\begin{array}{c}0.79 \\
(0.52-1.22)\end{array}$ & & 0.110 & $\begin{array}{c}0.92 \\
(0.57-1.49)\end{array}$ & \\
\hline & $\mathrm{A} / \mathrm{A}$ & 0.008 & 0.004 & $\begin{array}{c}0.50 \\
(0.08-3.03)\end{array}$ & & 0 & 0.00 (0.00-) & & 0.002 & $\begin{array}{c}0.22 \\
(0.02-2.10)\end{array}$ & & 0.003 & $\begin{array}{c}0.37 \\
(0.04-3.63)\end{array}$ & \\
\hline
\end{tabular}

Comparison between groups of patients and controls. (1) Relative Risk was calculated when the reference group (control) shows only non-mutated frequency. (2) OR and P-value were adjusted for gender. (*) OR adjusted by gender cannot be calculated due to lack of cases. 
at linkage disequilibrium, being the D' value $=0.3415$ and the $r$ value $=0.0504$. The minor allele frequency for the GC $\operatorname{rs} 3733359$ SNP was lower in the BLs group as compared to that of healthy individuals. This comparison remained statistically significant after FDR analysis.

The patients were grouped according to the underlying mechanism of the reaction. The first group was composed of all patients with drug hypersensitivity (DHR group), that is, (BLs + $\mathrm{CR}+\mathrm{SH})$. The second group of patients was composed of all patients with IgE-mediated drug hypersensitivity (D-IgE) (BLs + $\mathrm{SH})$. The third group of patients was composed of all patients with IgE-mediated reactions (BLs $+\mathrm{SH}+\mathrm{AR}+\mathrm{A})$, which were compared vs. healthy controls (Table 4). The two FCER1G SNPs displayed statistically significant differences in DHR and IgEmediated reactions as compared to control individuals, although the only difference that remained significant after FDR correction was that of the SNP FCER1G rs2070901 in patients with IgEmediated diseases (Table 4).

\section{Classification Models}

We built models including the three SNPs with significant associations in the combined dataset analyses phase, as well as the antecedents of atopy and gender, and the pseudo R-square values for each model (those which provide the best classification of each patient in its correct group) are shown in Table 5. All the models selected the FCER1G rs36233990 as a good variable. The variable "Antecedents of atopy" was also selected, although this was expected because none of the control individuals had antecedents of atopy. Model 1 was made by including the three SNPs with a significant $P$-value and all the clinical groups separately, as compared to control subjects. Model 2 included all patients with DHR compared to control individuals, and model 3 included all patients with IgE-mediated diseases vs. control individuals. The classifications per group are shown in Table 6. It is to be noted the high percentage of correct allocations using the three SNPs only (that is, without considering antecedents of atopy and gender). For comparison, we show in Table 6 the results of the same models including covariables such as antecedents of atopy, age and gender. The fact that antecedents of atopy predicted $100 \%$ of $\mathrm{AR}+\mathrm{A}$ patients has little value because control individuals had no antecedents. Age and gender, however, are not good predictors either (Table 6). Therefore, these covariables did not improve the predictive capacity of the models based on the SNPs.

\section{DISCUSSION}

Genetic variation is a major cause of interindividual differences in the susceptibility to a number of disorders. In this regard, a huge number of genetic association studies related to allergic disorders and drug hypersensitivity events have been carried out. Most of these studies have a case-control design interrogating only a few polymorphisms, typically, a few SNPs located within the coding region. The use of NGS techniques allows for a complete coverage of large areas thus revealing novel SNPs or analysing SNPs that are not included in most studies. In a previous NGS study in the promoter area of the genes encoding the COX-1 and COX-2 enzymes, we identified several novel SNPs. More

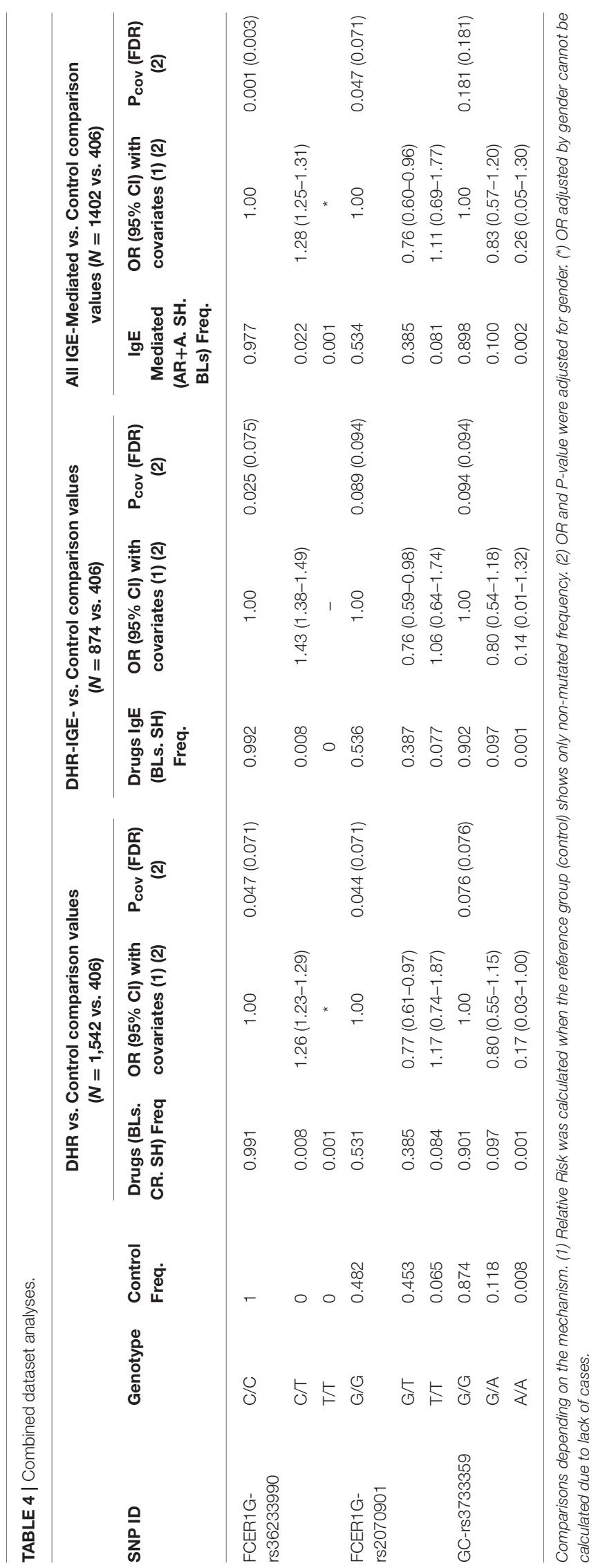


TABLE 5 | Statistically significant variables in each model and goodness-of-fit measures.

\begin{tabular}{|c|c|c|c|}
\hline Variables & $\begin{array}{c}\text { Model 1: } \\
\text { Single groups } \\
\text { model } \\
{\text { (p-value })^{*}}^{\text {mode }}\end{array}$ & $\begin{array}{c}\text { Model 2: } \\
\text { DHR Model } \\
\text { (BLs, CR, } \\
\text { SH)/Rhinitis+ } \\
\text { asthma/Control) } \\
\text { (p-value)* }\end{array}$ & $\begin{array}{c}\text { Model 3: } \\
\text { IgE Mediated Drugs } \\
\text { Model (BLs, } \\
\text { SH)/Rhinitis+ } \\
\text { asthma/CR/Control) } \\
\text { (p-value })^{\star}\end{array}$ \\
\hline $\begin{array}{l}\text { FCER1G } \\
\text { rs36233990 }\end{array}$ & 0.001 & 0.000 & 0.000 \\
\hline $\begin{array}{l}\text { FCER1G } \\
\text { rs2070901 }\end{array}$ & 0.520 & 0.169 & 0.337 \\
\hline $\begin{array}{l}\text { GC } \\
\text { rs3733359 }\end{array}$ & 0.810 & 0.517 & 0.766 \\
\hline $\begin{array}{l}\text { Antecedents } \\
\text { of atopy }\end{array}$ & 0.030 & 0.000 & 0.000 \\
\hline Gender & 0.000 & 0.106 & 0.137 \\
\hline \multicolumn{4}{|c|}{ Pseudo R-square } \\
\hline Cox and Snell & 0.522 & 0.520 & 0.521 \\
\hline Nagelkerke & 0.546 & 0.606 & 0.557 \\
\hline McFadden & 0.237 & 0.376 & 0.268 \\
\hline
\end{tabular}

*The overall effectiveness of the model was assessed by using the Chi-square statistic.

TABLE 6 | Prediction models

\begin{tabular}{lcc}
\hline $\begin{array}{l}\text { Observed } \\
\text { (clinical } \\
\text { classification) }\end{array}$ & $\begin{array}{c}\text { Predicted (Group } \\
\text { allocation according to } \\
\text { the model) SNPs only (\%) } \\
\text { correct }\end{array}$ & $\begin{array}{c}\text { Predicted (Group allocation } \\
\text { according to the model) SNPs } \\
\text { + Antecedents of atopy + } \\
\text { gender+ age (\%) correct }\end{array}$ \\
\hline AR+A $(n=481)$ & 4.1 & 98.2 \\
BLs $(n=230)$ & 49.0 & 7.0 \\
CR $(n=553)$ & 53.4 & 68.6 \\
SH $(n=300)$ & 0 & 12.3 \\
DHR $(n=1083)$ & 99.0 & 81.8 \\
DHR IgE-Mediated & 99.2 & 49.6 \\
$(n=530)$ & & 79.6 \\
All IgE-Mediated & 99.9 & \\
$(n=1,326)$ & & \\
\end{tabular}

than 70 SNPs modified transcription factor binding sites, either by disrupting existing sequences or by creating new binding sites (Agundez et al., 2014).

The present study is aimed to analyse the promoter areas of 16 genes related to allergic diseases and drug hypersensitivity reactions (DHRs). We have focused on the promoter gene region due to its crucial role in transcriptional activity and expression of the gene, as it has been observed for the SNPs located in the promoter of FCER1A (Potaczek et al., 2009), or IL13 (Cameron et al., 2006; Kiesler et al., 2009; Li et al., 2014). The rationale for the selection of the 16 genes included in this study is based on putative mechanisms involved this type of reactions. FCERI plays an essential role in IgE-mediated mechanisms and variants in FCERI genes have been previously described as genetic factors related to asthma (Cui et al., 2003; Kim et al., 2006; Palikhe et al., 2008; Joubert et al., 2011; Ramphul et al., 2014; Yang et al., 2014), allergy (Hasegawa et al., 2003; de Guia et al., 2015; Liao et al.,
2015; Amo et al., 2016a,b), and food sensitization (Liu et al. 2011; Hong and Wang, 2012). It has been also described that some variants in genes involved in the vitamin $\mathrm{D}$ pathway are related with asthma (Poon et al., 2004; Raby et al., 2004; Wjst, 2005; Wjst et al., 2006; Bossé et al., 2009; Saadi et al., 2009; Li et al., 2011; Pillai et al., 2011; Maalmi et al., 2013; Leung et al., 2015; Hutchinson et al., 2017), especially variations in genes regulated by vitamin $\mathrm{D}$, such as $I L 4$ and its receptor (Burchard et al., 1999; Donfack et al., 2005; Ober and Hoffjan, 2006; Battle et al., 2007; Michel et al., 2010; Baye et al., 2011; Hesselmar et al., 2012; Liu et al., 2012; Micheal et al., 2013; Nie et al., 2013; Zhu et al., 2013; Al-Muhsen et al., 2014; Berenguer et al., 2014; Klaassen et al., 2015; Zhang et al., 2015; Narozna et al., 2016) and IL13 (Black et al., 2009; Bottema et al., 2010; Palikhe et al., 2010; Cui et al., 2012; Accordini et al., 2016; Xu et al., 2017), which are also related to IgE (Marsh et al., 1994; Kabesch et al., 2006). According to previous research, the mechanisms involved in cross-reactions and selective ones are different, (Doña et al., 2012; Ayuso et al., 2013; Torres et al., 2014; Nissen et al., 2015; Amo et al., 2016a) and previously published results show that some variations, either related to FCERI or to vitamin $\mathrm{D}$, are strongly associated with IgE-mediated pathologies, like rs12135235 in FCER1A, rs144205117 in CYP2R1, rs1467664 in $R X R G$ or rs4303288 in VDR. Association between the rs 2070874 in IL4 and atopy and hypersensitivity, has been described in previously published works (Burchard et al., 1999; Donfack et al., 2005; Kabesch et al., 2006; Ober and Hoffjan, 2006; Kim et al., 2010; Madore and Laprise, 2010; Baye et al., 2011; Lu et al., 2011; Liu et al., 2012; Andiappan et al., 2013; Hsu et al., 2013; Micheal et al., 2013; Movahedi et al., 2013; Zhu et al., 2013; Berenguer et al., 2014; Caniatti et al., 2014; Li et al., 2014; de Guia et al., 2015; Klaassen et al., 2015; Zhang et al., 2015; Hua et al., 2016; Narozna et al., 2016).

Although binary logistic regression analyses pointed to six SNPs corresponding to RXRG, GC, IL4, VDR, and CYP24A1 (see the Results section), statistical significance for these SNPs was not supported after multinomial analysis, except for the GC SNP. By turn, two additional FCER1G SNPs, as well as the GC SNP, were statistically significant after multinomial analyses. It is important to note that the major findings obtained in the present study are novel, since only one of the three SNPs that remained after the multinomial analysis have been previously related with atopy or drug hypersensitivity. Among these, one of the FCER1G SNPs is novel and hence have not been studied before, and the other one has been related with food sensitization (Liu et al., 2011) and has been previously studied in patients with selective hypersensitivity to NSAIDs and allergic rhinitis without significant association (Amo et al., 2016a,b). After the NGS and combined dataset analyses phases, prediction models revealed that one of these SNPs, designated as FCER1G rs36233990 was correct in all models and it allowed an excellent prediction for patients with DHR, IgE-mediated DHR and all IgE-mediated diseases analyzed. It should be taken into consideration that the significant $p$-values observed for rs36233990 in case-control association analyses might be inflated because this SNP was not observed in controls. However, this is a commonly observed SNP in European populations, 
which underscores the need for large control sets. This is a limitation in this study. The rs36233990 variation is located in a regulatory region where multiple transcription factor binding sites exist. The variant allele $\mathrm{T}$ triggers the appearance of E2F-3:Prrxl1 complex and GKLF (KLF4). On the other hand, the variant allele $\mathrm{T}$ leads the disappearance of a binding site for the transcription factor p300. Our own previous findings supported a role of FCER gene variations in patients with $\mathrm{AR}+\mathrm{A}$, but not in patients with SH (Park et al., 2011; Amo et al., 2016a) which are consistent with those raised in this study. The minor allele of rs2070901 in FCERIG triggers the disappearance of a transcription factor binding site for ELK1: OC-2. The GC variation designated as rs3733359 is located in a splice region for transcripts 2 and 3 of GC, and in the 5' untranslated region for transcripts 1 and X1. This variant has been previously related to immune and other disorders (Jung et al., 2011; Wang et al., 2015; Xie et al., 2018). Our findings regarding the $G C$ polymorphism support the hypothesis of a relevant role of vitamin D in allergy (Hall and Agrawal, 2017; Tian and Cheng, 2017.

In summary, our findings show that the analysis of the gene promoters is useful for the identification of genetic biomarkers of risk for DHRs and $\mathrm{AR}+\mathrm{A}$. Models using these gene variations allow a high degree of prediction, that is, correct group allocations (Table 6) based on these SNPs only. It should be kept in mind that the variant allele frequencies for these SNPs are relatively low, that is, the frequency of carriers of the risk variants is relatively low, specially for the most significant SNP FCER1G rs36233990 ( $<2 \%$ of patients). The frequencies of carriers for other two SNPs are 47 and $10.5 \%$ for FCERIG rs2070901 and GC rs3733359, respectively. Therefore, the presence of these gene variations cannot explain, by itself, the development of most cases of DHR. However, the SNPs raised in this study, point to mechanisms involved in

\section{REFERENCES}

Ådjers, K., Luukkainen, A., Pekkanen, J., Hurme, M., and Huhtala, H., Renkonen, R., et al. (2017). Self-reported allergic rhinitis and/or allergic conjunctivitis associate with IL13 rs20541 polymorphism in finnish adult asthma patients. Int. Arch. Allergy Immunol. 172, 123-128. doi: 10.1159/000 456009

Accordini, S., Calciano, L., Bombieri, C., Malerba, G., Belpinati, F., Lo Presti, A. R., et al. (2016). An interleukin 13 polymorphism is associated with symptom severity in adult subjects with ever asthma. PLoS ONE 11:e0151292. doi: 10.1371/journal.pone.0151292

Agresti, A. (2003). Logit models for multinomial responses. Categ Data Anal. doi: 10.1002/0471249688.ch7

Agúndez, J. A., Ayuso, P., Cornejo-García, J. A., Blanca, M., Torres, M. J., Doña, I., et al. (2012). The diamine oxidase gene is associated with hypersensitivity response to non-steroidal anti-inflammatory drugs. PLOS ONE 7:e47571. doi: 10.1371/journal.pone.0047571

Agundez, J. A., Gonzalez-Alvarez, D. L., Vega-Rodriguez, M. A., Botello, E., and Garcia-Martin, E. (2014). Gene variants and haplotypes modifying transcription factor binding sites in the human cyclooxygenase 1 and 2 (PTGS1 and PTGS2) genes. Curr. Drug Metab. 15, 182-195. doi: 10.2174/138920021502140327180336

Al-Muhsen, S., Vazquez-Tello, A., Alzaabi, A., Al-Hajjaj, M. S., Al-Jahdali, H. H., and Halwani, R. (2014). IL-4 receptor alpha single-nucleotide
DHR and add novel information that can be used as a proof of mechanism.

\section{AUTHOR CONTRIBUTIONS}

EG-M and JA contributed conception and design of the study. JG-M, CC, JC-G, NB-L, GC, ID, MB, and MT recruited and characterized patients. MM performed the statistical analysis. GA wrote the first draft of the manuscript. MM, EG-M, and JA wrote sections of the manuscript. All authors contributed to manuscript critical revision with important intellectual contribution, read, and approved the submitted version.

\section{FUNDING}

This work was supported in part by Grants PI15/00303, PI15/00726, PI17/01593, PI18/00540 and ARADyAL RD16/0006/0001, RD16/0006/0004 and RD16/0006/0024 from Fondo de Investigación Sanitaria, Instituto de Salud Carlos III, Spain, IB16170 and GR18145 from Junta de Extremadura, Spain. Financed in part with FEDER funds from the European Union.

\section{ACKNOWLEDGMENTS}

JC-G is a researcher from the Miguel Servet Program (Ref CP14/00034), and ID from the Juan Rodés Program (Ref JR15/0036), both from the Carlos III National Health Institute, Spanish Ministry of Economy and Competitiveness).

\section{SUPPLEMENTARY MATERIAL}

The Supplementary Material for this article can be found online at: https://www.frontiersin.org/articles/10.3389/fgene. 2019.00582/full\#supplementary-material polymorphisms rs1805010 and rs1801275 are associated with increased risk of asthma in a Saudi Arabian population. Ann. Thorac. Med. 9, 81-86. doi: 10.4103/1817-1737.128849

Amo, G., Cornejo-García, J. A., García-Menaya, J. M., Cordobes, C., Torres, M. J., Esguevillas, G., et al. (2016b). FCERI and histamine metabolism gene variability in selective responders to NSAIDS. Front. Pharmacol. 7:353. doi: 10.3389/fphar.2016.00353

Amo, G., García-Menaya, J., Campo, P., Cordobés, C., Plaza Serón, M. C., Ayuso, P., et al. (2016a). A Nonsynonymous FCER1B SNP is associated with risk of developing allergic rhinitis and with IgE levels. Sci. Rep. 6:19724. doi: 10.1038/srep19724

Anderson, W. H., Koshy, B. T., Huang, L., Mosteller, M., Stinnett, S. W., Condreay, L. D., et al. (2013). Genetic analysis of asthma exacerbations. Ann. Allergy Asthma Immunol. 110, 416-422.e2. doi: 10.1016/j.anai.2013.04.002

Andiappan, A. K., Nilsson, D., Halldén, C., Yun, W. D., Säll, T., Cardell, L. O., et al. (2013). Investigating highly replicated asthma genes as candidate genes for allergic rhinitis. BMC Med. Genet. 14:51. doi: 10.1186/14712350-14-51

Antúnez, C., Martín, E., Cornejo-García, J. A., Blanca-Lopez, N. R., Pena, R., Mayorga, C., et al. (2006). Immediate hypersensitivity reactions to penicillins and other betalactams. Curr. Pharm. Des. 12, 3327-3333. doi: 10.2174/138161206778194042

Arshad, S. H., Karmaus, W., Kurukulaaratchy, R., Sadeghnejad, A., Huebner, M., and Ewart, S. (2008). Polymorphisms in the interleukin 13 and GATA 
binding protein 3 genes and the development of eczema during childhood. $B r$. J. Dermatol. 158, 1315-1322. doi: 10.1111/j.1365-2133.2008.08565.x

Ashley, S. E., Tan, H. T., Peters, R., Allen, K. J., Vuillermin, P., Dharmage, S. C., et al. (2017). Genetic variation at the Th2 immune gene IL13 is associated with IgE-mediated paediatric food allergy. Clin. Exp. Allergy 47, 1032-1037. doi: $10.1111 /$ cea.12942

Ayuso, P., Blanca-López, N., Doña, I., Torres, M. J., Guéant-Rodríguez, R. M., Canto, G., et al. (2013). Advanced phenotyping in hypersensitivity drug reactions to NSAIDs. Clin. Exp. Allergy 43, 1097-1109. doi: 10.1111/cea.12140

Battle, N. C., Choudhry, S., Tsai, H. J., Eng, C., Kumar, G., Beckman, K. B., et al. (2007). Ethnicity-specific gene-gene interaction between IL-13 and IL-4ralpha among African Americans with asthma. Am. J. Respir. Crit. Care Med. 175, 881-887. doi: 10.1164/rccm.200607-992OC

Baye, T. M., Butsch Kovacic, M., Biagini Myers, J. M., Martin, L. J., Lindsey, M., Patterson, T. L., et al. (2011). Differences in candidate gene association between european ancestry and african american asthmatic children. PLOS ONE 6:e16522. doi: 10.1371/journal.pone.0016522

Benjamini, Y., Drai, D., Elmer, G., Kafkafi, N., and Golani, I. (2001). Controlling the false discovery rate in behavior genetics research. Behav. Brain Res. 125, 279-284. doi: 10.1016/S0166-4328(01)00297-2

Benson, A. A., Toh, J. A., Vernon, N., and Jariwala, S. P. (2012). The role of vitamin D in the immunopathogenesis of allergic skin diseases. Allergy 67, 296-301. doi: 10.1111/j.1398-9995.2011.02755.x

Berenguer, A. G., Fernandes, A. T., Oliveira, S., Rodrigues, M., Ornelas, P., Romeira, D., et al. (2014). Genetic polymorphisms and asthma: findings from a case-control study in the Madeira island population. Biol. Res. 47:40. doi: 10.1186/0717-6287-47-40

Black, P. N., and Scragg, R. (2005). Relationship between serum 25hydroxyvitamin $\mathrm{d}$ and pulmonary function in the third national health and nutrition examination survey. Chest 128, 3792-3798. doi: 10.1378/chest.128.6.3792

Black, S., Teixeira, A. S., Loh, A. X., Vinall, L., Holloway, J. W., Hardy, R., et al. (2009). Contribution of functional variation in the IL13 gene to allergy, hay fever and asthma in the NSHD longitudinal 1946 birth cohort. Allergy 64, 1172-1178. doi: 10.1111/j.1398-9995.2009.01988.x

Blanca, M., Romano, A., Torres, M. J., Férnandez, J., Mayorga, C., Rodriguez, J., et al. (2009). Update on the evaluation of hypersensitivity reactions to betalactams. Allergy 64, 183-193. doi: 10.1111/j.1398-9995.2008.01924.x

Bossé, Y., Lemire, M., Poon, A. H., Daley, D., He, J. Q., Sandford, A., et al. (2009). Asthma and genes encoding components of the vitamin D pathway. Respir. Res. 10:98. doi: 10.1186/1465-9921-10-98

Bottema, R. W., Nolte, I. M., Howard, T. D., Koppelman, G. H., Dubois, A. E., de Meer, G., et al. (2010). Interleukin 13 and interleukin 4 receptoralpha polymorphisms in rhinitis and asthma. Int. Arch. Allergy Immunol. 153, 259-267. doi: 10.1159/000314366

Bouvy, J. C., De Bruin, M. L., and Koopmanschap, M. A. (2015). Epidemiology of adverse drug reactions in europe: a review of recent observational studies. Drug Saf. 38, 437-453. doi: 10.1007/s40264-015-0281-0

Brozek, J. L., Bousquet, J., Agache, I., Agarwal, A., Bachert, C., BosnicAnticevich, S., et al. (2017). Allergic rhinitis and its impact on asthma (ARIA) guidelines-2016 revision. J. Allergy Clin. Immunol. 140, 950-958. doi: 10.1016/j.jaci.2017.03.050

Burchard, E. G., Silverman, E. K., Rosenwasser, L. J., Borish, L., Yandava, C., Pillari, A., et al. (1999). Association between a sequence variant in the IL-4 gene promoter and FEV(1) in asthma. Am. J. Respir. Crit. Care Med. 160, 919-922. doi: 10.1164 /ajrccm.160.3.9812024

Burkhardt, J., Kirsten, H., Wolfram, G., Quente, E., and Ahnert, P. (2012). Differential allelic expression of IL13 and CSF2 genes associated with asthma. Genet. Mol. Biol. 35, 567-574. doi: 10.1590/S1415-47572012005000055

Camargo, C. A., Rifas-Shiman, S. L., Litonjua, A. A., Rich-Edwards, J. W., Weiss, S. T., Gold, D. R., et al. (2007). Maternal intake of vitamin D during pregnancy and risk of recurrent wheeze in children at 3 y of age. Am. J. Clin Nutr. 85, 788-795. doi: 10.1093/ajcn/85.3.788

Cameron, L., Webster, R. B., Strempel, J. M., Kiesler, P., Kabesch, M., Ramachandran, H., et al. (2006). Th2 cell-selective enhancement of human IL13 transcription by IL13-1112C > T, a polymorphism associated with allergic inflammation. J. Immunol. 177, 8633-8642. doi: 10.4049/jimmunol.17 7.12 .8633
Caniatti, M. C., Marchioro, A. A., Guilherme, A. L., and Tsuneto, L. T. (2014). Association of cytokines in individuals sensitive and insensitive to dust mites in a brazilian population. PLOS ONE 9:e107921. doi: 10.1371/journal.pone.0107921

Canto, M. G., Andreu, I., Fernandez, J., and Blanca, M. (2009). Selective immediate hypersensitivity reactions to NSAIDs. Curr. Opin. Allergy Clin. Immunol. 9, 293-297. doi: 10.1097/ACI.0b013e32832db943

Cantorna, M. T., Snyder, L., Lin, Y. D., and Yang, L. (2015). Vitamin $\mathrm{D}$ and $1,25(\mathrm{OH}) 2 \mathrm{D}$ regulation of $\mathrm{T}$ cells. Nutrients 7, 3011-3021. doi: 10.3390/nu7043011

Chen, C. J., Cheng, C. F., Lin, H. Y., Hung, S. P., Chen, W. C., and Lin, M. S. (2012). A comprehensive 4-year survey of adverse drug reactions using a network-based hospital system. J. Clin. Pharm. Ther. 37, 647-651. doi: 10.1111/j.1365-2710.2012.01359.x

Choi, W. A., Kang, M. J., Kim, Y. J., Seo, J. H., Kim, H. Y., Kwon, J. W., et al. (2012). Gene-gene interactions between candidate gene polymorphisms are associated with total IgE levels in Korean children with asthma. J. Asthma. 49, 243-252. doi: 10.3109/02770903.2012.660294

Cooper, J. D., Smyth, D. J., Walker, N. M., Stevens, H., Burren, O. S., Wallace, C., et al. (2011). Inherited variation in vitamin D genes is associated with predisposition to autoimmune disease type 1 diabetes. Diabetes 60, 1624-1631. doi: $10.2337 / \mathrm{db} 10-1656$

Cornejo-Garcia, J. A., Blanca-López, N., Doña, I., Andreu, I., Agúndez, J. A., Carballo, M., et al. (2009). Hypersensitivity reactions to nonsteroidal anti-inflammatory drugs. Curr. Drug Metab. 10, 971-980. doi: $10.2174 / 138920009790711841$

Cox, D. R., and Snell, E. J. (1989). Analysis of Binary Data, 2nd Edn. London: Taylor \& Francis

Cui, L., Jia, J., Ma, C. F., Li, S. Y., Wang, Y. P., Guo, X. M., et al. (2012). IL-13 polymorphisms contribute to the risk of asthma: a meta-analysis. Clin. Biochem. 45, 285-288. doi: 10.1016/j.clinbiochem.2011.12.012

Cui, T. P., Wang, L., Xie, J. G., Hu, L. H., and Wu, J. M. (2003). Study on the high-affinity $\operatorname{IgE}$ receptor beta gene polymorphism and its association with the susceptibility to allergic asthma in Han nationality of Hubei province. Zhonghua Yi Xue Yi Chuan Xue Za Zhi 20, 307-310.

de Guia, R. M., Echavez, M. D., Gaw, E. L., Gomez, M. R., Lopez, K. A., Mendoza, R. C., et al. (2015). Multifactor-dimensionality reduction reveals interaction of important gene variants involved in allergy. Int. J. Immunogenet. 42, 182-189. doi: $10.1111 /$ iji.12200

Doña, I., Barrionuevo, E., Blanca-Lopez, N., Torres, M. J., Fernandez, T. D., Mayorga, C., et al. (2014). Trends in hypersensitivity drug reactions: more drugs, more response patterns, more heterogeneity. J. Invest. Allergol. Clin. Immunol. 24, 143-153) quiz 1 following 153.

Doña, I., Blanca-López, N., Cornejo-García, J. A., Torres, M. J., Laguna, J. J., Fernández, J., et al. (2011). Characteristics of subjects experiencing hypersensitivity to non-steroidal anti-inflammatory drugs: patterns of response. Clin. Exp. Allergy 41, 86-95. doi: 10.1111/j.1365-2222.2010.03651.x

Doña, I., Blanca-López, N., Torres, M. J., García-Campos, J., García-Núñez, I., Gómez, F., et al. (2012). Drug hypersensitivity reactions: response patterns, drug involved, and temporal variations in a large series of patients. J. Invest. Allergol. Clin. Immunol. 22, 363-371.

Donfack, J., Schneider, D. H., Tan, Z., Kurz, T., Dubchak, I., Frazer, K. A., et al. (2005). Variation in conserved non-coding sequences on chromosome 5q and susceptibility to asthma and atopy. Respir. Res. 6:145. doi: 10.1186/1465-9921-6-145

Durham, S. R., Emminger, W., Kapp, A., de Monchy, J. G., Rak, S., Scadding, G. K., et al. (2012). SQ-standardized sublingual grass immunotherapy: confirmation of disease modification 2 years after 3 years of treatment in a randomized trial. J. Allergy Clin. Immunol. 129, 717-725.e5. doi: 10.1016/j.jaci.2011.12.973

European Commission (2008). Proposal for a Regulation Amending, as Regards Pharmacovigilance of Medicinal Products for Human Use. Regulation (EC) No 726/2004. Impact assessment. Available online at: http://ec.europa.eu/health/ files/pharmacos/pharmpacks_12_2008/pha.

Ferreira, M. A., Zhao, Z. Z., Thomsen, S. F., James, M., Evans, D. M., Postmus, P. E., et al. (2009). Association and interaction analyses of eight genes under asthma linkage peaks. Allergy 64, 1623-1628. doi: 10.1111/j.1398-9995.2009.02091.x

García-Martín, E., García-Menaya, J., Sánchez, B., Martínez, C., Rosendo, R., and Agúndez, J. A. (2007). Polymorphisms of histamine-metabolizing enzymes and 
clinical manifestations of asthma and allergic rhinitis. Clin. Exp. Allergy 37, 1175-1182. doi: 10.1111/j.1365-2222.2007.02769.x

Gomes, E., Cardoso, M. F., Praça, F., Gomes, L., Mariño, E., and Demoly, P. (2004). Self-reported drug allergy in a general adult Portuguese population. Clin. Exp. Allergy 34, 1597-1601. doi: 10.1111/j.1365-2222.2004.02070.x

Gomes, E. R., and Demoly, P. (2005). Epidemiology of hypersensitivity drug reactions. Curr. Opin. Allergy Clin. Immunol. 5, 309-316. doi: 10.1097/01.all.0000173785.81024.33

González, J. R., Armengol, L., Solé, X., Guinó, E., Mercader, J. M., Estivill, X., et al. (2007). SNPassoc: an R package to perform whole genome association studies. Bioinformatics 23, 644-645. doi: 10.1093/bioinformatics/btm025

Gonzalez, J. R., Lluis-Armengol, E. G., Sole, X., and Moreno, V. (2014). SNPsBased Whole Genome Association Studies. Available online at: https://CRAN. R-project.org/package $=$ SNPassoc

Granada, M, Wilk, JB, Tuzova, M., Strachan, D. P., Weidinger, S., Albrecht, E., et al. (2012). A genome wide Association study of plasma total IgE concentration in the framingham heart study. J. Allergy Clin. Immunol. 129, 840-845.e21. doi: 10.1016/j.jaci.2011.09.029

Hall, S. C., and Agrawal, D. K. (2017). Vitamin D and bronchial asthma: an overview of the last five years. Clin. Ther. 39, 917-929. doi: 10.1016/j.clinthera.2017.04.002

Han, J. C., Du, J., Zhang, Y. J., Qi, G. B., Li, H. B., Zhang, Y. J., et al. (2016). Vitamin D receptor polymorphisms may contribute to asthma risk. J. Asthma 53, 790-800. doi: 10.3109/02770903.2016.1158267

Hasegawa, M., Nishiyama, C., Nishiyama, M., Akizawa, Y., Mitsuishi, K., Ito, T., et al. (2003). A novel-66T/C polymorphism in Fc epsilon RI alpha-chain promoter affecting the transcription activity: possible relationship to allergic diseases. J. Immunol. 171, 1927-1933. doi: 10.4049/jimmunol.171.4.1927

Hesselmar, B., Enelund, A. C., Eriksson, B., Padyukov, L., Hanson, L. Å., and Aberg, N. (2012). The heterogeneity of asthma phenotypes in children and young adults. J. Allergy 2012:163089. doi: 10.1155/2012/163089

Hong, X., and Wang, X. (2012). Early life precursors, epigenetics, and the development of food allergy. Semin. Immunopathol. 34, 655-669. doi: $10.1007 / \mathrm{s} 00281-012-0323-y$

Hsu, J., Avila, P. C., Kern, R. C., Hayes, M. G., Schleimer, R. P., and Pinto, J. M. (2013). Genetics of chronic rhinosinusitis: state of the field and directions forward. J. Allergy Clin. Immunol. 131, 977-993.e5. doi: 10.1016/j.jaci.2013.01.028

Hua, L., Zuo, X. B., Bao, Y. X., Liu, Q. H., Li, J. Y., Lv, J., et al. (2016). Fourlocus gene interaction between IL13, IL4, FCER1B, and ADRB2 for asthma in Chinese Han children. Pediatr. Pulmonol. 51, 364-371. doi: 10.1002/ppul.23322

Hur, G. Y., Ye, Y. M., Koh, D. H., Kim, S. H., and Park, H. S. (2013). IL4 receptor $\alpha$ polymorphisms may be a susceptible factor for work-related respiratory symptoms in bakery workers. Allergy Asthma Immunol Res. 5, 371-376. doi: 10.4168/aair.2013.5.6.371

Hutchinson, K, Kerley, CP, Faul, J., Greally, P., Coghlan, D., Louw, M., et al. (2017). Vitamin D receptor variants and uncontrolled asthma. Eur. Ann. Allergy Clin. Immunol. 50:108-116. doi: 10.23822/EurAnnACI.1764-1489.46

Ismail, M. F., Elnady, H. G., and Fouda, E. M. (2013). Genetic variants in vitamin D pathway in Egyptian asthmatic children: a pilot study. Hum. Immunol. 74, 1659-1664. doi: 10.1016/j.humimm.2013.08.284

Joubert, B. R., Reif, D. M., Edwards, S. W., Leiner, K. A., Hudgens, E. E., Egeghy, P., et al. (2011). Evaluation of genetic susceptibility to childhood allergy and asthma in an African American urban population. BMC Med. Genet. 12:25. doi: 10.1186/1471-2350-12-25

Jung, K. H., Kim, T. H., Sheen, D. H., Lim, M. K., Lee, S. K., Kim, J. Y., et al. (2011). Associations of vitamin d binding protein gene polymorphisms with the development of peripheral arthritis and uveitis in ankylosing spondylitis. $J$. Rheumatol. 38, 2224-2229. doi: 10.3899/jrheum.101244

Juul, S. (2012). Epidemiologi Og Evidens. 2nd Edn. København: Munksgaard.

Juul, S., and Frydenberg, M. (2016). EpiBasic. Available online at: http:// ph.medarbejdere.au.dk/undervisning-og-uddannelse/software/ (accessed February 06, 2019).

Kabesch, M., Schedel, M., Carr, D., Woitsch, B., Fritzsch, C., Weiland, S. K., et al. (2006). IL-4/IL-13 pathway genetics strongly influence serum IgE levels and childhood asthma. J. Allergy Clin. Immunol. 117, 269-274. doi: 10.1016/j.jaci.2005.10.024
Karaca, S., Civelek, E., Karaca, M., Sahiner, U. M., Ozgul, R. K., Kocabas, C. N., et al. (2016). Allergy-specific phenome-wide association study for immunogenes in turkish children. Sci. Rep. 6:33152. doi: 10.1038/srep 33152

Kiesler, P., Shakya, A., Tantin, D., and Vercelli, D. (2009). An allergy-associated polymorphism in a novel regulatory element enhances IL13 expression. Hum. Mol. Genet. 18, 4513-4520. doi: 10.1093/hmg/ddp411

Kim, B. S., Park, S. M., Uhm, T. G., Kang, J. H., Park, J. S., Jang, A. S., et al. (2010). Effect of single nucleotide polymorphisms within the interleukin-4 promoter on aspirin intolerance in asthmatics and interleukin- 4 promoter activity. Pharmacogenet. Genomics 20, 748-758. doi: 10.1097/FPC.0b013e3283402155

Kim, S. H., Bae, J. S., Holloway, J. W., Lee, J. T., Suh, C. H., Nahm, D. H., et al. (2006). A polymorphism of MS4A2 (-109T > C) encoding the beta-chain of the high-affinity immunoglobulin E receptor (FcepsilonR1beta) is associated with a susceptibility to aspirin-intolerant asthma. Clin. Exp. Allergy 36, 877-883. doi: $10.1111 / j .1365-2222.2006 .02443 . x$

Kinet, J. P. (1999). The high-affinity IgE receptor ( $\mathrm{Fc}$ epsilon RI): from physiology to pathology. Аnnu. Rev. Immunol. 17, 931-972. doi: 10.1146/annurev.immunol.17.1.931

Klaassen, E. M., Penders, J., Jöbsis, Q., van de Kant, K. D., Thijs, C., Mommers, M., et al. (2015). An ADAM33 polymorphism associates with progression of preschool wheeze into childhood asthma: a prospective case-control study with replication in a birth cohort study. PLOS ONE 10:e0119349. doi: 10.1371/journal.pone.0119349

Knutsen, A. P., Vijay, H. M., Kariuki, B., Santiago, L. A., Graff, R., Wofford, J. D., et al. (2010). Association of IL-4RA single nucleotide polymorphisms, HLA-DR and HLA-DQ in children with Alternaria-sensitive moderate-severe asthma. Clin. Mol. Allergy 8:5. doi: 10.1186/1476-7961-8-5

Kowalski, M. L., Asero, R., Bavbek, S., Blanca, M., Blanca-Lopez, N., Bochenek, G., et al. (2013). Classification and practical approach to the diagnosis and management of hypersensitivity to nonsteroidal anti-inflammatory drugs. Allergy 68, 1219-1232. doi: 10.1111/all.12260

Kruse, R. L., and Vanijcharoenkarn, K. (2018). Drug repurposing to treat asthma and allergic disorders: progress and prospects. Allergy 73, 313-322. doi: $10.1111 /$ all.13305

Kumar, A., Das, S., Agrawal, A., Mukhopadhyay, I., and Ghosh, B. (2015). Genetic association of key Th1/Th2 pathway candidate genes, IRF2, IL6, IFNGR2, STAT4 and IL4RA, with atopic asthma in the Indian population. J. Hum. Genet. 60, 443-448. doi: 10.1038/jhg.2015.45

Lacombe-Barrios, J, Gomez, F, Perez, N, et al. (2018). Accurate of the diagnosis of allergy reactions at the Emergency Department. J. Invest. Allergol. Clin. Immunol. doi: 10.18176/jiaci.0313. [Epub ahead of print].

Lasky-Su, J., Lange, N., Brehm, J. M., Damask, A., Soto-Quiros, M., Avila, L., et al. (2012). Genome-wide association analysis of circulating vitamin D levels in children with asthma. Hum. Genet. 131, 1495-1505. doi: 10.1007/s00439-012-1185-z

Leung, T. F., Wang, S. S., Tang, M. F., Kong, A. P., Sy, H. Y., Hon, K. L., et al. (2015). Childhood asthma and spirometric indices are associated with polymorphic markers of two vitamin D 25-hydroxylase genes. Pediatr. Allergy Immunol. 26, 375-382. doi: $10.1111 /$ pai. 12392

Li, F., Jiang, L., Willis-Owen, S. A., Zhang, Y., and Gao, J. (2011). Vitamin D binding protein variants associate with asthma susceptibility in the Chinese han population. BMC Med. Genet. 12:103. doi: 10.1186/1471-235012-103

Li, J., Lin, L. H., Wang, J., Peng, X., Dai, H. R., Xiao, H., et al. (2014). Interleukin4 and interleukin-13 pathway genetics affect disease susceptibility, serum immunoglobulin E levels, and gene expression in asthma. Ann. Allergy Asthma Immunol. 113, 173-179.e1. doi: 10.1016/j.anai.2014.05.004

Li, T., Ren, Z., Deng, Y., Wang, Y., and Zhou, H. (2016). Lack of association between RAD50-IL13 polymorphisms and pediatric asthma susceptibility in Northeastern Han Chinese. J. Asthma 53, 114-118. doi: 10.3109/02770903.2015.1067322

Li, X., Ampleford, E. J., Howard, T. D., Moore, W. C., Torgerson, D. G., Li, H., et al. (2012). Genome-wide association studies of asthma indicate opposite immunopathogenesis direction from autoimmune diseases. J. Allergy Clin. Immunol. 130, 861-8.e7. doi: 10.1016/j.jaci.2012. 04.041 
Li, X., Howard, T. D., Zheng, S. L., Haselkorn, T., Peters, S. P., Meyers, D. A., et al. (2010). Genome-wide association study of asthma identifies RAD50IL13 and HLA-DR/DQ regions. J. Allergy Clin. Immunol. 125, 328-335.e11. doi: $10.1016 /$ j.jaci.2009.11.018

Liao, E. C., Chang, C. Y., Hsieh, C. W., Yu, S. J., Yin, S. C., and Tsai, J. J. (2015). An exploratory pilot study of genetic marker for ige-mediated allergic diseases with expressions of fcepsilonrlalpha and cepsilon. Int. J. Mol. Sci. 16, 9504-9519. doi: $10.3390 /$ ijms 16059504

Linneberg, A. (2011). The increase in allergy and extended challenges. Allergy 66 (Suppl. 9), 1-3. doi: 10.1111/j.1398-9995.2011.02619.x

Liu, S., Li, T., and Liu, J. (2012). Interleukin-4 rs2243250 polymorphism is associated with asthma among Caucasians and related to atopic asthma. Cytokine 59, 364-369. doi: 10.1016/j.cyto.2012.05.006

Liu, X., Wang, G., Hong, X., Wang, D., Tsai, H. J., Zhang, S., et al. (2011). Genevitamin $\mathrm{D}$ interactions on food sensitization: a prospective birth cohort study. Allergy 66, 1442-1448. doi: 10.1111/j.1398-9995.2011.02681.x

Lu, M. P., Chen, R. X., Wang, M. L., Zhu, X. J., Zhu, L. P., Yin, M., et al. (2011). Association Study on IL4, IL13 and IL4RA polymorphisms in mitesensitized persistent allergic rhinitis in a chinese population. PLoS ONE 6:e27363. doi: 10.1371/journal.pone.0027363

Maalmi, H., Sassi, F. H., Berraies, A., Ammar, J., Hamzaoui, K., and Hamzaoui, A. (2013). Association of vitamin D receptor gene polymorphisms with susceptibility to asthma in Tunisian children: a case control study. Hum. Immunol. 74, 234-240. doi: 10.1016/j.humimm.2012.11.005

Madore, A. M., and Laprise, C. (2010). Immunological and genetic aspects of asthma and allergy. J. Asthma Allergy 3, 107-121. doi: 10.2147/JAA.S8970

Marsh, D. G., Neely, J. D., Breazeale, D. R., Ghosh, B., Freidhoff, L. R., EhrlichKautzky, E., et al. (1994). Linkage analysis of IL4 and other chromosome 5 q31.1 markers and total serum immunoglobulin E concentrations. Science 264, 1152-1156. doi: 10.1126/science.8178175

Matys, V., Fricke, E., Geffers, R., Gössling, E., Haubrock, M., Hehl, R., et al. (2003). TRANSFAC: transcriptional regulation, from patterns to profiles. Nucl. Acids Res. 31, 374-378. doi: 10.1093/nar/gkg108

Matys, V., Kel-Margoulis, O. V., Fricke, E., Liebich, I., Land, S., BarreDirrie, A., et al. (2006). TRANSFAC and its module TRANSCompel: transcriptional gene regulation in eukaryotes. Nucl. Acids Res. 34:D108-D110. doi: $10.1093 /$ nar/gkj143

McFadden, D. (1974). "Conditional logit: analysis of qualitative choice behavior," in Frontiers in Ecnometrics, ed P. Zarembka (New York, NY: Academic Press), 105-142.

McFadden, D. (1977). Quantitative Methods for Analyzing Travel Behaviour of Individuals: Some Recent Developments. Cowles Foundation Discussion Papers 474, Cowles Foundation for Research in Economics, Yale University.

Messaad, D., Sahla, H., Benahmed, S., Godard, P., Bousquet, J., and Demoly, P. (2004). Drug provocation tests in patients with a history suggesting an immediate drug hypersensitivity reaction. Ann. Intern. Med. 140, 1001-1006. doi: 10.7326/0003-4819-140-12-200406150-00009

Micheal, S., Minhas, K., Ishaque, M., Ahmed, F., and Ahmed, A. (2013). IL-4 gene polymorphisms and their association with atopic asthma and allergic rhinitis in Pakistani patients. J. Invest. Allergol. Clin. Immunol. 23, 107-111.

Michel, S., Liang, L., Depner, M., Klopp, N., Ruether, A., Kumar, A., et al. (2010). Unifying candidate gene and GWAS approaches in asthma. PLoS ONE 5:e13894. doi: 10.1371/journal.pone.0013894

Moffatt, M. F., Gut, I. G., Demenais, F., Strachan, D. P., Bouzigon, E., Heath, S., et al. (2010). A large-scale, consortium-based genomewide association study of asthma. N. Engl. J. Med. 363, 1211-1221. doi: 10.1056/NEJMoa0906312

Movahedi, M., Amirzargar, A. A., Nasiri, R., Hirbod-Mobarakeh, A., Farhadi, E., Tavakol, M., et al. (2013). Gene polymorphisms of Interleukin-4 in allergic rhinitis and its association with clinical phenotypes. Am. J. Otolaryngol. 34, 676-681. doi: 10.1016/j.amjoto.2013.05.002

Nagelkerke, NJD. (1991). A note on a general definition of the coefficient of determination. Biometrika 78, 691-692. doi: 10.1093/biomet/78.3.691

Narozna, B., Hoffmann, A., Sobkowiak, P., Schoneich, N., Breborowicz, A., and Szczepankiewicz, A. (2016). Polymorphisms in the interleukin 4, interleukin 4 receptor and interleukin 13 genes and allergic phenotype: a case control study. Adv. Med. Sci. 61, 40-45. doi: 10.1016/j.advms.2015.07.003

Nie, W., Zang, Y., Chen, J., and Xiu, Q. (2013). Association between Interleukin-4 Receptor $\alpha$ Chain (IL4RA) I50V and Q551R Polymorphisms and asthma risk: an update meta-analysis. PLoS ONE 8:e69120. doi: 10.1371/journal.pone.0069120

Nissen, C. V., Bindslev-Jensen, C., and Mortz, C. G. (2015). Hypersensitivity to non-steroidal anti-inflammatory drugs (NSAIDs): classification of a Danish patient cohort according to EAACI/ENDA guidelines. Clin. Transl. Allergy 5:10. doi: 10.1186/s13601-015-0052-0

Ober, C., and Hoffjan, S. (2006). Asthma genetics the long and winding road to gene discovery. Genes Immun. 7:6364284. doi: 10.1038/sj.gene.6364284

Overton, N. L., Denning, D. W., Bowyer, P., and Simpson, A. (2016). Genetic susceptibility to allergic bronchopulmonary aspergillosis in asthma: a genetic association study. Allergy Asthma Clin. Immunol. 12:47. doi: 10.1186/s13223-016-0152-y

Ozdoganoglu, T., and Songu, M. (2012). The burden of allergic rhinitis and asthma. Ther. Adv. Respir. Dis. 6, 11-23. doi: 10.1177/1753465811431975

Palikhe, N. S., Kim, S. H., Cho, B. Y., Choi, G. S., Kim, J. H., Ye, Y. M., et al. (2010). IL-13 Gene Polymorphisms are Associated With Rhinosinusitis and Eosinophilic Inflammation in Aspirin Intolerant Asthma. Allergy Asthma Immunol Res. 2, 134-140. doi: 10.4168/aair.2010.2.2.134

Palikhe, N. S., Kim, S. H., Cho, B. Y., Ye, Y. M., Hur, G. Y., and Park, H. S. (2008). Association of three sets of high-affinity IgE receptor (FcepsilonR1) polymorphisms with aspirin-intolerant asthma. Respir. Med. 102, 1132-1139. doi: 10.1016/j.rmed.2008.03.017

Papadopoulou, A., Kouis, P., Middleton, N., Kolokotroni, O., Karpathios, T., Nicolaidou, P., et al. (2015). Association of vitamin D receptor gene polymorphisms and vitamin D levels with asthma and atopy in Cypriot adolescents: a case-control study. Multidiscip. Respir. Med. 10:26. doi: 10.1186/s40248-015-0025-0

Park, H. W., and Tantisira, K. G. (2017). Genetic signatures of asthma exacerbation. Allergy Asthma Immunol. Res. 9, 191-199. doi: 10.4168/aair.2017. 9.3.191

Park, K. Y., Park, M. K., Kim, E. J., Lee, M. K., and Seo, S. J. (2011). FCeRI gene promoter polymorphisms and total IgE levels in susceptibility to atopic dermatitis in korea. J. Korean Med. Sci. 26, 870-874. doi: $10.3346 / \mathrm{jkms} .2011 .26 .7 .870$

Paternoster, L., Standl, M., Chen, C. M., Ramasamy, A., Bønnelykke, K., Duijts, L., et al. (2011). Meta-analysis of genome-wide association studies identifies three new risk loci for atopic dermatitis. Nat. Genet. 44, 187-192. doi: 10.1038/ng.1017

Pértegas Díaz, S., and Pita Fernández, S. (2003). Cálculo del poder estadístico de un estudio. Cad Atención Primaria. 10, 59-63.

Pillai, D. K., Iqbal, S. F., Benton, A. S., Lerner, J., Wiles, A., Foerster, M., et al. (2011). Associations between genetic variants in vitamin D metabolism and asthma characteristics in young African Americans: a pilot study. J. Invest. Med. 59, 938-946. doi: 10.2310/JIM.0b013e318220df41

Pino-Yanes, M., Gignoux, C. R., Galanter, J. M., Levin, A. M., Campbell, C. D., Eng, C., et al. (2015). Genome-wide association study and admixture mapping reveal new loci associated with total IgE levels in Latinos. J. Allergy Clin. Immunol. 135, 1502-1510. doi: 10.1016/j.jaci.2014.10.033

Platts-Mills, T. A. (2001). The role of immunoglobulin $\mathrm{E}$ in allergy and asthma. Am. J. Respir. Crit. Care Med. 164:S1-5. doi: 10.1164/ajrccm.164.supplement_1.2103024

Poon, A. H., Laprise, C., Lemire, M., Montpetit, A., Sinnett, D., Schurr, E., et al. (2004). Association of vitamin D receptor genetic variants with susceptibility to asthma and atopy. Am. J. Respir. Crit. Care Med. 170, 967-973. doi: 10.1164/rccm.200403-412OC

Potaczek, D. P., and Kabesch, M. (2012). Current concepts of IgE regulation and impact of genetic determinants. Clin. Exp. Allergy 42, 852-871. doi: 10.1111/j.1365-2222.2011.03953.x

Potaczek, D. P., Maeda, K., Wang, Q. H., Nakano, N., Kanada, S., Stepien, E., et al. (2009). FcepsilonRIalpha gene-18483A $>$ C polymorphism affects transcriptional activity through YY1 binding. Immunogenetics 61, 649-655. doi: 10.1007/s00251-009-0391-x

Potaczek, D. P., Michel, S., Sharma, V., Zeilinger, S., Vogelberg, C., von Berg, A., et al. (2013). Different FCER1A polymorphisms influence IgE levels in asthmatics and non-asthmatics. Pediatr. Allergy Immunol. 24, 441-449. doi: $10.1111 /$ pai. 12083

Raby, B. A., Lazarus, R., Silverman, E. K., Lake, S., Lange, C., Wjst, M., et al. (2004). Association of vitamin D receptor gene polymorphisms with 
childhood and adult asthma. Am. J. Respir. Crit. Care Med. 170, 1057-1065. doi: $10.1164 / \mathrm{rccm} .200404-447 \mathrm{OC}$

Ramasamy, A., Kuokkanen, M., Vedantam, S., Gajdos, Z. K., Couto Alves, A., Lyon, H. N., et al. (2012). Genome-wide association studies of asthma in population-based cohorts confirm known and suggested loci and identify an additional association near HLA. PLoS ONE 7:e44008. doi: 10.1371 /journal.pone. 0044008

Ramphul, K., Lv, J., Hua, L., Liu, Q. H., Fang, D. Z., Ji, R. X., et al. (2014). Single nucleotide polymorphisms predisposing to asthma in children of Mauritian Indian and Chinese Han ethnicity. Brazi. J. Med. Biol. Res. 47, 394-397. doi: 10.1590/1414-431X20143751

Robinson, C. L., Baumann, L. M., Gilman, R. H., Romero, K., Combe, J. M., Cabrera, L., et al. (2012). The Peru Urban versus Rural Asthma (PURA) Study: methods and baseline quality control data from a crosssectional investigation into the prevalence, severity, genetics, immunology and environmental factors affecting asthma in adolescence in Peru. BMJ Open 2:e000421. doi: 10.1136/bmjopen-2011-000421

Rondon, C, Blanca-Lopez, N, Campo, P., Mayorga, C., Jurado-Escobar, R., Torres, M. J., et al. (2017). Specific immunotherapy in local allergic rhinitis: A randomized, double-blind placebo-controlled trial with Phleum pratense subcutaneous allergen immunotherapy. Allergy 73, 905-915. doi: 10.1111/all.13350

Saadi, A., Gao, G., Li, H., Wei, C., Gong, Y., and Liu, Q. (2009). Association study between vitamin $\mathrm{D}$ receptor gene polymorphisms and asthma in the chinese han population: a case-control study. BMC Med. Genet. 10:71. doi: 10.1186/1471-2350-10-71

Sadeghnejad, A., Karmaus, W., Arshad, S. H., Kurukulaaratchy, R., Huebner, M., and Ewart, S. (2008). IL13 gene polymorphisms modify the effect of exposure to tobacco smoke on persistent wheeze and asthma in childhood, a longitudinal study. Respir. Res. 9:2. doi: 10.1186/1465-9921-9-2

Sharma, V., Michel, S., Gaertner, V., Franke, A., Vogelberg, C., von Berg, A., et al. (2014). A role of FCER1A and FCER2 polymorphisms in IgE regulation. Allergy 69, 231-236. doi: 10.1111/all.12336

Suaini, N. H., Zhang, Y., Vuillermin, P. J., Allen, K. J., and Harrison, L. C. (2015). Immune modulation by vitamin $\mathrm{D}$ and its relevance to food allergy. Nutrients 7, 6088-6108. doi: 10.3390/nu7085271

Sun, L., Xue, W., Li, J., Zhou, Z., and Han, W. (2017). Palm dermatoglyphs and interleukin-4 receptor polymorphisms in asthma. Biomed. Rep. 6, 21-26. doi: 10.3892/br.2016.803

Szczeklik, A., and Nizankowska-Mogilnicka, E. S. M. (2009). Middleton's Allergy Principles and Practice, eds N. Adkinson, W. Busse, B. Bochner, S. Holgate, and R. Lemanske (London: Mosby Inc; Elsevier), 1227-1243.

Tian, H. Q., Chen, X. Y., Lu, Y., Lu, W. M., Wang, M. L., Zhao, H. L., et al. (2015). Association of VDR and CYP2R1 Polymorphisms with Mite-Sensitized Persistent Allergic Rhinitis in a Chinese Population. PLoS ONE 10:e0133162. doi: 10.1371/journal.pone.0133162

Tian, H. Q., and Cheng, L. (2017). The role of vitamin D in allergic rhinitis. Asia Pac. Allergy 7, 65-73. doi: 10.5415/apallergy.2017.7.2.65

Torres, M. J., Mayorga, C., Blanca-López, N., and Blanca, M. (2014). Hypersensitivity reactions to beta-lactams. EXS 104, 165-184. doi: 10.1007/978-3-0348-0726-5_11

Veldman, C. M., Cantorna, M. T., and DeLuca, H. F. (2000). Expression of 1,25Dihydroxyvitamin D3 receptor in the immune system. Arch. Biochem. Biophys. 374, 334-338. doi: 10.1006/abbi.1999.1605

Wallace, D. V., Dykewicz, M. S., Bernstein, D. I., Blessing-Moore, J., Cox, L., Khan, D. A., et al. (2008). The diagnosis and management of rhinitis: an updated practice parameter. J. Allergy Clin. Immunol. 122 (Suppl. 2), S1-84. doi: 10.1016/j.jaci.2008.06.003

Wang, Y., Wang, O., Li, W., Ma, L., Ping, F., Chen, L., et al. (2015). Variants in vitamin $\mathrm{d}$ binding protein gene are associated with gestational diabetes mellitus. Medicine 94:e1693. doi: 10.1097/MD.0000000000001693
Weidinger, S., Gieger, C., Rodriguez, E., Baurecht, H., Mempel, M., Klopp, N., et al. (2008). Genome-wide scan on total serum IgE levels identifies FCER1A as novel susceptibility locus. PLoS Genet. 4:e1000166. doi: 10.1371/journal.pgen.1000166

Wigginton, JE, Cutler, DJ, and Abecasis, GR. (2005). A note on exact tests of hardy-weinberg equilibrium. Am. J. Hum. Genet. 76, 887-893. doi: 10.1086/4 29864

Wjst, M. (2005). Variants in the vitamin D receptor gene and asthma. BMC Genet. 6:2. doi: 10.1186/1471-2156-6-2

Wjst, M., Altmüller, J., Faus-Kessler, T., Braig, C., Bahnweg, M., and André, E. (2006). Asthma families show transmission disequilibrium of gene variants in the vitamin $\mathrm{D}$ metabolism and signalling pathway. Respir. Res. 7:60. doi: $10.1186 / 1465-9921-7-60$

Xie, C. N., Yue, M., Huang, P., Tian, T., Fan, H. Z., Wu, M. P., et al. (2018). Vitamin D binding protein polymorphisms influence susceptibility to hepatitis C virus infection in a high-risk Chinese population. Gene 679, 405-411. doi: 10.1016/j.gene.2018.09.021

Xu, Y., Li, J., Ding, Z., Li, J., Li, B., Yu, Z., et al. (2017). Association between IL-13 +1923C/T polymorphism and asthma risk: a meta-analysis based on 26 case-control studies. Biosci. Rep. 37, 1-13. doi: 10.1042/BSR201 60505

Yang, H. J., Zheng, L., Zhang, X. F., Yang, M., and Huang, X. (2014). Association of the MS4A2 gene promoter C-109T or the 7th exon E237G polymorphisms with asthma risk: a meta-analysis. Clin. Biochem. 47, 605-611. doi: 10.1016/j.clinbiochem.2014.01.022

Zhang, S., Li, Y., and Liu, Y. (2015). Interleukin-4-589C/T polymorphism is associated with increased pediatric asthma risk: a meta-analysis. Inflammation 38, 1207-1212. doi: 10.1007/s10753-014-0086-9

Zhang, Y., Wang, Z., and Ma, T. (2017). Associations of Genetic Polymorphisms relevant to metabolic pathway of vitamin $\mathrm{d} 3$ with development and prognosis of childhood bronchial asthma. DNA Cell Biol. 36, 682-692. doi: $10.1089 /$ dna.2017.3730

Zhao, D. D., Yu, D. D., Ren, Q. Q., Dong, B., Zhao, F., and Sun, Y. H. (2017). Association of vitamin $\mathrm{D}$ receptor gene polymorphisms with susceptibility to childhood asthma: a meta-analysis. Pediatr. Pulmonol. 52, 423-429. doi: $10.1002 /$ ppul. 23548

Zhou, J., Zhou, Y., Lin, L. H., Wang, J., Peng, X., Li, J., et al. (2012). Association of polymorphisms in the promoter region of FCER1A gene with atopic dermatitis, chronic uticaria, asthma, and serum immunoglobulin E levels in a Han Chinese population. Hum. Immunol. 73, 301-305. doi: 10.1016/j.humimm.2011. 12.001

Zhu, N., Gong, Y., Chen, X. D., Zhang, J., Long, F., He, J., et al. (2013). Association between the polymorphisms of interleukin-4, the interleukin-4 receptor gene and asthma. Chin. Med. J. 126, 2943-2951.

Zuberbier, T., Lötvall, J., Simoens, S., Subramanian, S. V., and Church, M. K. (2014). Economic burden of inadequate management of allergic diseases in the European Union: a GA(2) LEN review. Allergy 69, 1275-1279. doi: $10.1111 /$ all.12470

Conflict of Interest Statement: The authors declare that the research was conducted in the absence of any commercial or financial relationships that could be construed as a potential conflict of interest.

Copyright (0 2019 Amo, Martí, García-Menaya, Cordobés, Cornejo-García, BlancaLópez, Canto, Doña, Blanca, Torres, Agúndez and García-Martín. This is an openaccess article distributed under the terms of the Creative Commons Attribution License (CC BY). The use, distribution or reproduction in other forums is permitted, provided the original author(s) and the copyright owner(s) are credited and that the original publication in this journal is cited, in accordance with accepted academic practice. No use, distribution or reproduction is permitted which does not comply with these terms. 